\begin{tabular}{|c|c|}
\hline $\begin{array}{c}\text { Universidade } \\
\text { de Brasília }\end{array}$ & $\begin{array}{c}\text { UNIVESIDADE FEDERAL } \\
\text { DA PARAÍBA }\end{array}$ \\
\hline UNIVERSIDADE FEDERAL DO \\
RIO GRANDE DO NORTE
\end{tabular}

\title{
RELAÇÃO ENTRE ELISÃO FISCAL E PRÁTICAS SOCIALMENTE RESPONSÁVEIS EM EMPRESAS BRASILEIRAS
}

\author{
VITÓRIA ESTANISLAU DE AGUIAR FERNANDES
}


UNIVERSIDADE DE BRASÍLIA - UnB

\section{Reitor:}

Professor Doutor Ivan Marques de Toledo Camargo

Vice-Reitor:

Professor Doutora Sônia Nair Báo

Decano de Pesquisa e Pós-Graduação:

Professor Doutor Jaime Martins de Santana

Diretor da Faculdade de Economia, Administração e Contabilidade:

Professor Doutor Roberto de Goes Ellery Júnior

Chefe do Departamento de Ciências Contábeis e Atuariais:

Professor Doutor José Antonio de França, Doutor.

Coordenador Geral do Programa Multiinstitucional e Inter-regional de Pós Graduação em Ciências Contábeis da UnB, UFPB e UFRN

Professor Doutor Rodrigo de Souza Gonçalves 


\title{
RELAÇÃO ENTRE ELISÃO FISCAL E PRÁTICAS SOCIALMENTE RESPONSÁVEIS EM EMPRESAS BRASILEIRAS
}

\begin{abstract}
Dissertação apresentada como requisito parcial à obtenção do título de Mestre em Ciências Contábeis do Programa Multiinstitucional e Inter-Regional de Pós-Graduação em Ciências Contábeis da Universidade de Brasília, da Universidade Federal da Paraíba e da Universidade Federal do Rio Grande do Norte.
\end{abstract}

Linha de Pesquisa: Impactos da Contabilidade na Sociedade

Orientador: Prof. Dr. Rodrigo de Souza Gonçalves 
Fernandes, Vitória Estanislau de Aguiar

RELAÇÃO ENTRE ELISÃO FISCAL E PRÁTICAS SOCIALMENTE RESPONSÁVEIS EM EMPRESAS BRASILEIRAS / Vitória Estanislau DE Aguiar Fernandes. Brasília, DF, 2015.

$82 \mathrm{f}$.

Orientador: Prof Dr. Rodrigo De Sousa Gonçalves

Dissertação (mestrado) - Universidade de Brasília. Faculdade de Economia, Administração e Ciências Contábeis e Atuariais - FACE.

Programa Multiinstitucional e Inter-Regional de Pós-Graduação em Ciências Contábeis (UnB/UFPB/UFRN).

1. Elisão fiscal 2. Effective Tax Rate (ETR) 3. Responsabilidade Social Corporativa (RSC) 4. Práticas Tributárias. 


\section{RELAÇÃO ENTRE ELISÃO FISCAL E PRÁTICAS SOCIALMENTE RESPONSÁVEIS EM EMPRESAS BRASILEIRAS}

Dissertação apresentada como requisito parcial à obtenção do título de Mestre em Ciências Contábeis do Programa Multiinstitucional e Inter-Regional de Pós-Graduação em Ciências Contábeis da Universidade de Brasília, da Universidade Federal da Paraíba e da Universidade Federal do Rio Grande do Norte.

\section{Comissão Avaliadora:}

\section{Prof. Dr. Rodrigo de Souza Gonçalves}

Programa Multiinstitucional e Inter-regional de Pós-Graduação em Ciências Contábeis da UnB/UFPB/ UFRN

(Presidente da Banca)

\section{Prof. Dr. César Augusto Tiburcio Silva}

Programa Multiinstitucional e Inter-regional de Pós-Graduação em Ciências Contábeis da UnB/UFPB/UFRN

(Membro Examinador Interno)

Prof. Dr. Prof. Dr. Elionor Farah Jreige Weffort Fundação Escola de Comércio Alves Penteado - FECAP

(Membro Examinador Externo) 


\section{AOS MEUS PAIS}

Sérgio Fernandes e Wanda Fernandes, pelo amor e dedicação incondicionais. Por lutarem para que se abrissem as portas do meu futuro. Vocês sempre foram minha base, meu exemplo e eu sempre irei honrá-los.

\section{À MINHA AMADA AVÓ}

Crizolita que colaborou diretamente e foi essencial nesta minha caminhada nos estudos. Desde que tomei as minhas decisões não me faltaram auxílio, orações (as mais fortes), carinho, afeto e segurança. Obrigada por tudo o que fez e tem feito por mim, eu não poderia ter uma "mãe com açúcar" melhor. 


\section{AGRADECIMENTOS}

A Deus, pela dádiva de viver e, sobretudo, por me reservar oportunidades únicas e me guiar em todos os caminhos percorridos, sendo socorro bastante presente nas dificuldades. Sou grata por me abençoar com toda força, sabedoria e saúde. Cada bênção foi essencial durante esse ciclo que se fecha com a conclusão deste estudo.

Ao meu orientador, Prof. Dr. Rodrigo de Souza Gonçalves, por literalmente me adotar, pela disposição e paciência em me orientar de maneira singular. Ser justo, me acolher, incentivar, compreender as minhas dificuldades e principalmente não desistir de mim ultrapassou o comportamento esperado de um orientador. Obrigada por me presentear com este tema e por me proporcionar discussões valiosas nesta área. Sem ele, definitivamente, não seria possível concluir esta dissertação.

Aos professores do Programa Multiinstitucional e Inter-Regional de Pós-Graduação em Ciências Contábeis (UnB/UFPB/UFRN), por todo conhecimento agregado, sinto uma imensa admiração e os tenho como forte exemplo nesta caminhada acadêmica.

Aos professores que participaram da qualificação Prof ${ }^{a}$. Dr ${ }^{a}$ Márcia Reis Machado e Prof. Dr. César Augusto Tibúrcio Silva, bem como à Prof ${ }^{\mathrm{a}}$ Dr $^{\mathrm{a}}$ Elionor Farah Jreige Weffort pelas importantes contribuições.

Aos colegas do mestrado pelo convívio, união e por tornarem a caminhada "mais suave".

A alguns "anjos" que me foram concedidos ao longo desta caminhada principalmente com a mudança a Brasília: Tatiane Sá, Bianca Fellet, Rafael Portella e Rafael Reis. As contribuições foram tantas e tão grandiosas que eu só consigo dizer que o meu coração é repleto de gratidão e não me restam dúvidas de que a chegada e permanência de cada um ao longo desta caminhada só pode ser obra Dele.

Aos meus amigos e familiares que, mesmo distantes, me apoiaram e foram tão tolerantes com minha ausência durante este período. Sinto que nossos corações permanecem ligados e o carinho de cada um é de suma importância para a conquista dos meus sonhos.

Gostaria de Agradecer também a todos que de alguma forma contribuíram para esse trabalho e para a conclusão desta etapa, e a todos que não acreditaram que eu pudesse chegar até aqui, pois sem os obstáculos não há evolução. 
"EM TUDO DAI GRAÇAS"

(1 Tessalonicenses 5:18) 


\section{RESUMO}

O objetivo deste estudo é verificar se existe associação entre a elisão físcal e a Responsabilidade Social Corporativa. Considera-se que empresas certificadas como socialmente responsáveis possuem aversão ao risco. Como as práticas tributárias de elisão fiscal representam um risco para empresa, espera-se que empresas socialmente responsáveis apresentem menores índices de elisão tributária. Para cumprir esse objetivo foi tomado como base uma amostra de 72 empresas listadas na BM\&FBOVESPA que participam e não participam do Índice de Sustentabilidade Empresarial (ISE). Para tanto, foi utilizado como forma de mensuração da elisão fiscal: Effective Tax Rate (ETR). A metodologia utilizada constitui-se em um estudo empírico-analítico, com base em uma amostra onde foram coletadas informações entre os anos de 2009 a 2013. A coleta de dados foi realizada através de consultas às Demonstrações Financeiras, notas explicativas das empresas em escopo e dados contidos na Economática ${ }^{\circledR}$. Para tratamento dos dados, além da análise descritiva, foram realizadas análise de regressão com dados em painel. Os resultados evidenciam menores índices de ETR para as empresas do grupo de controle que é composto pelas empresas não certificadas pelo ISE. Com base na análise dos dados o apresentados é possível afirmar que as empresas socialmente responsáveis, denotadas pelo ISE, possuem uma maior tendência às práticas de elisão fiscal. Como resultado, a hipótese principal do estudo - há relação das empresas brasileiras que apresentam práticas socialmente responsáveis face à questão da elisão tributária - foi aceita comprovando haver diferença significante entre as práticas de empresas certificadas e não certificadas pelo ISE.

Palavras-chave: Elisão fiscal, Effective Tax Rate (ETR), Responsabilidade Social Corporativa (RSC) e práticas tributárias. 


\begin{abstract}
The objective of this study is to investigate the association between tax avoidance and corporate social responsibility. It is considered that companies certified as socially responsible have risk aversion. As the tax practices of tax avoidance pose a risk to the company, it is expected that socially responsible companies have lower rates of tax avoidance. To accomplish this goal was taken on a sample of 72 companies listed on the BM \& FBOVESPA participating and not participating in the Corporate Sustainability Index (ISE). Thus, it was used as a means of measuring the tax avoidance: Effective Tax Rate (ETR). The methodology used is in an empirical-analytic study, based on a sample where information was collected between the years 2009 to 2013. Data collection was conducted through consultations to the financial statements, notes to the companies in scope and data contained in Economática ${ }^{\circledR}$. To processing of data, in addition to descriptive analysis were conducted regression analysis with panel data. The results show lower rates of ETR for companies in the control group consists of the companies not certified by ISE. Based on the analysis of the data presented it is clear that socially responsible companies, denoted by the ISE, have a greater tendency to the practices of tax avoidance. As a result, the study's hypothesis - no relationship of Brazilian companies with socially responsible practices face the issue of tax avoidance - was accepted proving there significant differences between the practices of certified companies and not certified by ISE.
\end{abstract}

Keywords: Tax Avoidance, Effective Tax Rate (ETR), Corporate Social Responsibility (CSR) and Tax Practices. 


\section{LISTA DE QUADROS}

Quadro 1 - Quantidade de empresas por setor ...................................................... 48

Quadro 2 - Variáveis utilizadas no estudo e sinal esperado .......................................53

Quadro 3 - Matriz de correlação das variáveis do estudo............................................62

Quadro 4- Resumo dos resultados-Elisão Fiscal (ETR) e variáveis independentes ......66 


\section{LISTA DE FIGURAS}

Figura 1 - Modelo para a performance social corporativa …..................................... 25 


\section{LISTA DE TABELAS}

Tabela 1 - Empresas componentes da pesquisa ao final de cada ano........................... 48

Tabela 2 - Empresas pesquisadas - 2009 a 2013 .................................................. 54

Tabela 3 - Distribuição por prática ou grupo de práticas tributárias escolhidas - 2009 a 2013.

Tabela 4 - Distribuição por prática ou grupo de práticas tributárias adotadas por empresas certificadas pelo ISE - 2009 a 2013.

Tabela 5 - Distribuição por prática ou grupo de práticas tributárias adotadas por empresas não certificadas pelo ISE - 2009 a 2013

Tabela 6 - Estatísticas descritivas da Efetive Tax Rate (ETR).

Tabela 7 - Quartis e desvio padrões das medidas de mensuração da elisão fiscal para as empresas certificadas e não certificadas

Tabela 8 - Teste de Hausman para estimação de modelo em painel com efeitos aleatórios em cross-secion

Tabela 9 - Resultados da estimação dos dados em painel com efeitos aleatórios seccionais para variável dependente elisão fiscal (ETR) 


\section{LISTA DE ABREVIATURAS E SIGLAS}

AICPA: American Institute of Certified Public Accountants

BM\&FBOVESPA: Bolsa de Valores de São Paulo

Cofins: Contribuição para o Financiamento da Seguridade Social

CSLL: Contribuição Social sobre o Lucro Líquido

CVM: Comissão de Valores Mobiliários

ETR: Effective Tax Rate

Finam: Fundo de Investimento na Amazônia

Finor: Fundo de Investimento do Nordeste

FNC: Fundo Nacional da Cultura

FUNRES: Fundo de Recuperação Econômica do Estado do Espírito Santo

GAAP ETR: Generally Accepted Accounting Principles

IBPT: Instituto Brasileiro de Planejamento e Tributação

IPI: Imposto sobre Produtos Industrializados

IRPJ: Imposto de Renda da Pessoa Jurídica

ISE: Índice de Sustentabilidade Empresarial

JSCP: Juros sobre Capital Próprio

LAIR: Lucro antes do imposto de renda

LALUR: Livro de Apuração do Lucro Real

PAT: Programa de Alimentação do Trabalhador

PDTA: Programas de Desenvolvimento Tecnológico Agropecuário

PDTI: Programas de Desenvolvimento Tecnológico Industrial

PEPS: primeiro que entra é o primeiro que sai

PIB: Produto Interno Bruto

PIS: Programa de Integração Social

Pronac: Programa Nacional de Apoio à Cultura

RIR/99: Regulamento do Imposto de Renda de 1999

RSC: Responsabilidade Social Corporativa

UEPS: ou o último que entra é o primeiro que sai 


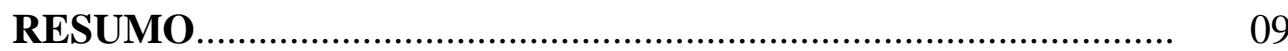

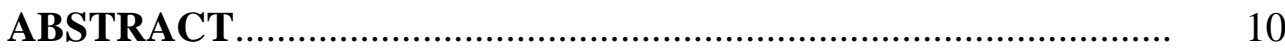

LISTA DE QUADROS 11

LISTA DE FIGURAS 12

LISTA DE TABELAS 13

LISTA DE ABREVIATURAS E SIGLAS 14

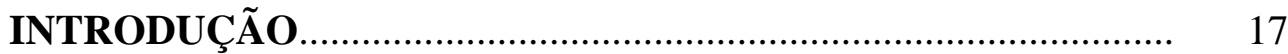

$1.1 \quad$ Contextualização................................................................................ 17

$1.2 \quad$ Objetivos................................................................................. 20

$1.3 \quad$ Justificativa e Relevância....................................................................... 21

2 REFERENCIAL TEÓRICO ....................................................... 22

2.1 Elisão fiscal e responsabilidade social............................................... 22

2.2 Responsabilidade social corporativa e elisão fiscal: estudos anteriores... 30

2.3 Indicadores de Elisão Fiscal............................................................. 32

2.4 Variáveis que explicam a Elisão Fiscal...……………………………... 34

2.4.1 Depreciação Acelerada e Depreciação Acelerada Incentivada........... 35

2.4.2 Juros sobre Capital Próprio.................................................................... 36

2.4.3 Incentivos Fiscais Federais..................................................................

2.4.4 Idade de oferta pública da ação.............................................................. 42

2.4.5 Serviços de auditoria............................................................................ 42

2.4.6 Tamanho da empresa.......................................................................... 43

3 PROCEDIMENTOS METODOLÓGICOS...................................... 44

$3.1 \quad$ Natureza e Tipo de Pesquisa 44

$3.2 \quad$ Objeto de estudo.......................................................................... 45

3.2.1 População e Amostra........................................................................... 46

3.3 Variáveis dependentes e independentes.................................................. 49

$3.4 \quad$ Base para regressão................................................................... 51

$4 \quad$ TRATAMENTO E ANÁLISE DOS RESULTADOS .......................... 54

$4.1 \quad$ Análise Descritiva......................................................................... 
4.2 Análise da regressão com dados em painel: Elisão Fiscal e

Responsabilidade Social..

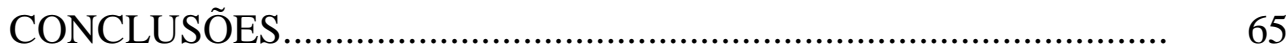

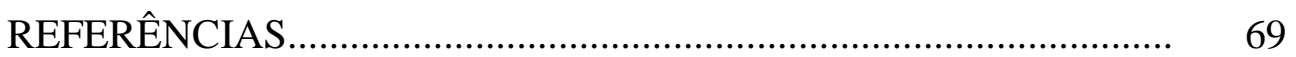

ANEXO A - MENSURAÇÕES DA ELISÃO FISCAL...................... 78

ANEXO B — EMPRESAS CERTIFICADAS PELO ISE

ANEXO C — EMPRESAS NÃO CERTIFICADAS PELO ISE 


\section{INTRODUÇÃO}

\subsection{Contextualização}

Ao considerar que a tributação se trata de uma transferência de recursos do setor privado para o setor público, o pagamento de impostos, taxas, emolumentos e contribuições pode produzir efeitos no ambiente empresarial, tanto no aspecto financeiro quanto no econômico. Para Santiago (2006, p. 17) "a tributação altera o comportamento dos agentes econômicos e interfere em decisões acerca da destinação de recursos, atuando como um limitador do crescimento das empresas". Dessa forma, os impostos representam um fator chave em muitas decisões empresariais.

Por considerar que o pagamento de tributos pode ser visto como um dos muitos custos de exploração de uma empresa, uma das estratégias para ela se tornar ou se manter competitiva é a minimização da quantidade de impostos na incidência sobre as operações.

O Brasil tem uma elevada carga tributária em relação a outros países. Segundo estudo feito pelo Instituto Brasileiro de Planejamento e Tributação (IBPT), a carga tributária nacional, em 2013, ficou em torno de 36\% do Produto Interno Bruto (PIB). Além da elevada carga tributária, o Brasil apresenta um complexo sistema tributário vigente, estes fatores justifica a busca, por meio dos contribuintes, de formas para reduzir, ou até mesmo eliminar, a incidência do tributo sobre suas operações. Segundo Piqueras (2010), o gerenciamento de tributos é influenciado pela maximização do retorno dos acionistas, pela redução dos custos políticos, pelos incentivos contratuais e pelas mudanças na percepção dos mercados, quando os impostos são determinantes no preço das ações, sempre com a finalidade de reduzir a carga tributária incidente sobre a empresa.

Ainda segundo Piqueras (2010) as ações voltadas para a redução de impostos ocorrida antes do fato gerador são conhecidas como elisão fiscal e não se confundem com a sonegação (evasão fiscal). Isso porque essas ações operam dentro dos limites legais, podendo ser decorrentes da própria lei ou resultantes do aproveitamento de lacunas e brechas existentes.

Ações gerenciais desenvolvidas exclusivamente para reduzir os tributos, por meio de elisão fiscal, estão se tornando um fenômeno cada vez mais comum no meio empresarial e observado em vários países, fenômeno esse que vem sendo objeto de 
pesquisa de diversos autores (JANSSEN, 2000; DICICCO, 2002; GALLO, 2002; YLÖNEN; LAINE, 2014; REGO, 2003; SILVA et al., 2004; PIQUERAS, 2010; LANIS; RICHARDSON, 2011, 2012, 2014).

A elisão fiscal é especialmente prejudicial para os países em desenvolvimento, considerando que os governos dependem fortemente da arrecadação dos tributos para obter suas receitas e pelo fato do Estado apresentar fraca capacidade em fiscalizar e controlar as práticas de elisão fiscal (JENKINS; NEWELL, 2013).

Freedman (2003) afirma que o pagamento de impostos pelas empresas possui implicações sociais, pois, a partir das contribuições, surge a função vital de ajudar a financiar a provisão de bens públicos na sociedade (como exemplo, educação, defesa nacional, saúde pública, transporte público e aplicação da lei). Assim, uma das finalidades da arrecadação de recursos é a de atingir o bem comum, atendendo às despesas públicas, sendo dessa forma um assunto de interesse da sociedade.

Sob esse prisma insere-se também a temática da Responsabilidade Social Corporativa (RSC). Diversos autores (AVI-YONAH, 2008; CAMARGO, 2009; CARROLL, 1979, 1998; CARROLL; SHABANA, 2010; COUTINHO; MACEDOSOARES, 2002; FISHER, 2014; FREEDMAN, 2003; GOMES, 2007; GONÇALVES, 2006; HEAL, 2015) apresentaram o interesse nessas duas áreas (práticas tributárias e de responsabilidade social), sendo tal interesse se deva em razão dos aspectos conceituais que cercam a temática de RSC frente as ações internas que as empresas devem desenvolver face à sociedade.

A RSC está associada ao papel da empresa na sociedade, por aquela poder influenciar na vida das pessoas e nas estratégias das organizações. No início do século XXI, houve a crescente valorização de uma nova postura empresarial, voltada não só para a obtenção de lucros, mas para o relacionamento com a sociedade e para os impactos gerados sobre a mesma (SOUZA; COSTA, 2012, p. 214)

Coutinho e Macedo-Soares (2002, p. 76) ressaltam que, "devido ao agravamento de problemas sociais e ambientais por todo o planeta e à dificuldade dos governos em solucioná-los, as forças da sociedade estão passando por um processo de reorganização". É nesse contexto que as empresas são pressionadas a adotarem uma postura socialmente responsável na condução dos seus negócios.

Para Tinoco (2001), a RSC pressupõe o reconhecimento da comunidade e da sociedade como partes integrantes da organização, que possuem necessidades a 
serem atendidas. É também o exercício de sua consciência moral e cívica, advinda da ampla compreensão de seu papel no desenvolvimento da sociedade.

Segundo Souza e Costa (2012, p. 224) "ao mesmo tempo em que contribui para o desenvolvimento da sociedade, a empresa pode obter vantagens com as práticas de responsabilidade social e sustentabilidade".

Heal (2005) afirma que a RSC pode ser um elemento rentável na estratégia corporativa, uma vez que contribui para a manutenção de relações importantes para a sustentação da organização em longo prazo. Ainda para Carroll (1979), uma definição adequada de Responsabilidade Social Corporativa (RSC) envolve todas as obrigações que as empresas têm para com a sociedade, que devem incorporar as categorias econômicas, legais, éticas e discricionárias (filantrópicas). Para Fisher (2014), a RSC geralmente se refere às obrigações e inclinações voluntárias de corporações, para perseguir fins sociais.

Conforme Smith (2005), as atividades de responsabilidade social na forma de igualdade em oportunidade de emprego, compromissos, políticas e práticas ambientalmente responsáveis aumentam o valor em longo prazo para os acionistas, reduzindo os custos e riscos. Entre a discussão das adições que as empresas podem obter, por meio do engajamento em atividades de responsabilidade social, Kurucz et al. (2008) identificam quatro categorias de benefícios: (1) redução de custos e riscos; (2) obtenção de vantagem competitiva; (3) o desenvolvimento de reputação e legitimidade; e (4) criação de valor sinérgico.

Segundo Avi-Yonah (2008), partindo das categorias identificadas, o fundamento da crítica às empresas declaradas socialmente responsáveis é a de que as ações sociais seriam ilegítimas se tais empresas utilizassem mecanismos para evitar ou postergar o pagamento de tributos e, ainda, aumentar sua lucratividade em razão de tal prática.

A expectativa de que um maior nível de responsabilidade social seja um fator relevante na tentativa de evitar as consequências da elisão fiscal também pode ser baseada na visão de que há uma dependência mútua das empresas e da sociedade. Isso implica que as decisões de cunho empresarial e político-social devem seguir o princípio do valor compartilhado, ou seja, as escolhas devem beneficiar ambos os lados (PORTER; KRAMER, 2006).

Uma das razões que associa a tributação como uma questão de responsabilidade social das empresas, conforme mencionado, é o risco. Assim como 
questões sociais e ambientais, as práticas de elisão fiscal representa fator de risco para as empresas. Para De la Penhã (2014), o risco mais relevante está associado à reputação, de modo que empresas, cujo sucesso depende de uma boa reputação, devem tratar a elisão fiscal como uma prática que eleva os seus riscos e, consequentemente, distancia-se das práticas socialmente responsáveis.

A relação de impostos sobre as sociedades são questões que têm atraído atenção na literatura acadêmica (GRAY et al., 1995; ROBERTS, 1992; DEEGAN, 2002; DESAI; DHARMAPALA, 2006a; FRANK et al., 2009; CHEN et al., 2010). No entanto, pesquisas anteriores pouco se voltaram para a análise de como a responsabilidade social e a elisão fiscal poderiam estar associadas (FISHER, 2014; HUSEYNOV; KLAMM, 2012; FREEDMAN, 2003; DESAI; DHARMAPALA, 2006b; LANDOLF, 2006; LANIS; RICHARDSON, 2012, 2014).

No Brasil, verifica-se um estágio mais avançando no que tange à quantidade de pesquisas acerca da (RSC), devido, entre outros fatores, às exigências dos investidores em relação a informações mais transparentes sobre a gestão. As pesquisas sobre a elisão fiscal passaram a despertar o interesse, sobretudo, em razão da elevada carga tributária brasileira, cujo cenário tributário complexo incentivou análises teóricas e empíricas.

Nota-se que esta carência de pesquisas que tratem da relação entre tributos e responsabilidade social está associada ao fato de que a tributação tem um impacto direto sobre os resultados. Tradicionalmente, os pagamentos de tributos são vistos como transferências de acionistas para o Estado. Por isso, as empresas são resistentes em incorporar a tributação como um problema atrelado à responsabilidade social, devido ao provável conflito com seus acionistas (DESAI; DHARMAPALA, 2006).

De acordo com Fisher (2014), outra possível justificativa para esta falta de atenção da elisão fiscal, em relação à responsabilidade social, pode ser atribuída ao fato de que a tributação não possui apelo sensacionalista como outras questões da responsabilidade social, como os abusos de direitos humanos e ambientais que geralmente chamam mais atenção. Entretanto, segundo De la Peña (2014), com a mudança da percepção do papel exercido pelas organizações na sociedade, a ligação entre responsabilidade social e tributação se trata de um fator "emergente", de modo que os escândalos da elisão fiscal estão se tornando um tema atraente para a mídia. 
Diante do exposto e do cenário brasileiro, este trabalho tem o intuito de responder a seguinte indagação: Qual a relação das empresas brasileiras que apresentam práticas socialmente responsáveis face à questão da elisão tributária?

\subsection{Objetivos}

Este estudo tem por objetivo analisar se empresas socialmente responsável possuem menor prática de elisão fiscal.

Para alcançar o objetivo proposto, foi necessário desenvolver os seguintes objetivos específicos:

- identificar e mensurar variáveis que capturem a prática de elisão fiscal;

- elaborar grupo de controle de empresas não certificadas como socialmente responsáveis;

- testar a relação da prática de elisão fiscal em empresas socialmente responsáveis (certificadas) e o grupo de controle denominado como não certificadas.

\subsection{Justificativa e Relevância}

O presente estudo, tendo por base as discussões a respeito da elisão fiscal, principalmente em face da responsabilidade social, pretende contribuir para o debate do tema, devido à sua relevância acadêmica e prática. Esse tema é importante no âmbito empresarial, político e econômico, porém, nota-se uma carência de discussões na área contábil-tributária.

A pesquisa contribui para a literatura sob diferentes prismas. Inicialmente, sabe-se que todo litígio é um risco e esta pesquisa possibilita a constatação de qual grupo de empresas deve ser percebido como provável de maior risco. Esse estudo também busca fornecer evidências empíricas sobre as empresas socialmente responsáveis, se elas estão menos propensas às práticas de elisão fiscal.

Ao analisar pesquisas fora do cenário brasileiro (LANIS E RICHARDSON, 2011, 2012; HOI et al., 2013) nota-se que os estudos encontram que há relação entre o nível de elisão físcal e o nível de responsabilidade social das empresas, reforçando a necessidade de se incluir e aprofundar a tributação no debate sobre questões relacionadas à responsabilidade social. 
Como no Brasil esse é um tema pouco investigado, esta pesquisa avança em busca de evidências acerca das empresas brasileiras com práticas de responsabilidade social, se estão menos propensas a realizarem a prática de elisão físcal, preenchendo uma lacuna verificada na literatura. Isso porque não foram encontrados estudos nacionais que documentassem a associação entre a Responsabilidade Social Corporativa (RSC) e o Tax Avoidance (Elisão fiscal).

\section{REFERENCIAL TEÓRICO}

\subsection{Elisão fiscal e Responsabilidade Social}

A humanidade se desenvolve em grande parte pela sua capacidade de organização em grupos sociais. Segundo Burns, Lerner e Meacham (2003), a organização social esteve presente desde os tempos mais primórdios, visto que os homens são seres sociais.

Segundo Réa (2010) diante do processo evolutivo da sociedade, os responsáveis pela administração da coletividade passaram a ter a necessidade de arrecadar parte dos rendimentos individuais, a fim de financiar seus custos. Surge, então, uma das formas de manutenção do Estado, que é justamente a arrecadação de tributos, em que os produtores recolhem impostos em troca da segurança e da proteção oferecidas pelo Estado.

Segundo Abraham (2007, p. 57):

O tributo, na atualidade, passa a ser visto como o preço da liberdade, custo este originário do pacto social firmado entre o cidadão e o Estado (e cidadãos entre si), em que o primeiro cede parcela do seu patrimônio (originário do capital ou trabalho), em favor do segundo, que lhe fornecerá bens e serviços para uma existência digna e satisfatória em sociedade.

O tributo financia o Estado por meio de arrecadação e da intervenção na propriedade privada e na renda dos indivíduos. O Brasil, especificamente, é marcado por uma elevada carga tributária além de um complexo sistema tributário vigente. Além destes fatores específicos, e por ter interferência direta na renda dos indivíduos, a norma tributária pode ser vista como norma de rejeição social, o que leva as entidades particulares a procurarem meios de se evitar o pagamento de tributos.

Conforme Piqueras (2006), os tributos, afetam os planejamentos estratégicos financeiros, os custos empresariais e influenciam também o comportamento 
do mercado. Segundo Gutierrez (2006) o ato de planejar um tributo é organizar todas as etapas de sua apuração, de forma a antecipar o quanto será pago, preparando cada operação para que seja gerado o menor valor possível, de acordo com a lei.

O planejamento tributário em grande parte está voltado a comportamentos adotados por pessoas jurídicas, considerando-as contribuintes que assumem a maior parte da carga tributária imposta pelo Estado, além de serem objeto de frequentes fiscalizações por parte do Fisco.

Gubert (2003, p. 33) define planejamento tributário como “o conjunto de condutas comissivas ou omissivas da pessoa física ou jurídica realizadas antes ou depois da ocorrência do fato gerador, destinadas a reduzir, mitigar, transferir ou postergar legal e licitamente os ônus dos tributos".

Nesse sentido, Castro (2002, p. 6) comenta:

\begin{abstract}
Ninguém se organiza para pagar mais impostos. No mercado competitivo das modernas relações empresariais, o processo de planejamento, como um todo, passou a ser necessidade básica. O planejamento tributário insere-se em um procedimento amplo e geral que deve preceder a qualquer novo negócio ou alteração de rumo no mundo empresarial. Ele objetiva o que qualquer outro planejamento visa: a eficiência, em termos de dispêndio com tributos significará sempre pagar menos, dentro dos limites da lei.
\end{abstract}

De acordo com Knuutinen (2014), existem diferentes formas de reduzir os impostos, os quais podem ser divididos em elisão fiscal (Tax Avoidance), evasão fiscal (Tax Evasion) e planejamento tributário (Tax Planning). É importante fazer uma distinção terminológica, pois há equívocos do termo evasão físcal para caracterizar a conduta omissiva ou comissiva lícita a ser realizada antes da ocorrência do fato gerador da obrigação tributária.

Ao considerar a busca das entidades por meios de evitar o pagamento de tributos, tem-se que esses meios podem, por si só, ser ou não ser lícitos. Partindo desses meios, tem-se em destaque os conceitos de elisão e evasão fiscal. Moreira (2003) apresenta que as definições de elisão e evasão fiscal não são unânimes na doutrina. Acerca das divergências conceituais, o autor afirma que existe certo consenso no sentido de que elisão fiscal corresponde à economia lícita de tributos e evasão fiscal à sonegação ou simulação (que pode ser absoluta ou relativa, esta última denominada dissimulação).

Fisher (2014) esclarece que apesar de algumas vezes os termos "elisão" e "evasão" serem utilizados como sinônimos, a "evasão fiscal" normalmente se refere à 
redução de pagamento de impostos de forma ilegal, enquanto a "elisão físcal", à redução de pagamentos de impostos legalmente.

A evasão fiscal, segundo Knuutinen (2014), seria qualquer esforço por parte do contribuinte para reduzir tributos, por exemplo, por meio de emissão de relatórios fiscais incompletos ou falsos. Nesse caso, o objetivo é alcançado de maneira criminosa, por meio de atos fraudulentos.

Segundo Abrahão (2011) a elisão fiscal é equiparada à economia lícita de tributos, ao cumprir com as obrigações tributárias. A palavra "elisão" é derivada do latim Elisione e significa ato ou efeito de elidir, eliminar, suprir.

Desse modo é possível diferenciar a evasão fiscal uma vez que traz implicitamente um comportamento ilícito por parte do contribuinte, podendo-se afirmar que toda ação de evasão tributária é consciente, dolosa ou intencional e visa evitar ou eliminar, reduzir ou retardar o pagamento de tributos. Muitas vezes o conceito de elisão fiscal se confunde com o conceito de planejamento tributário, mas na realidade a elisão fiscal é um tipo de planejamento tributário.

Conforme apresenta Rego (2003), a elisão fiscal é um planejamento tributário que produz resultados eficazes, na qual busca a redução do valor presente dos pagamentos dos impostos e, por conseguinte, o aumento da taxa de retorno pré-imposto dos investidores.

De acordo com as pesquisas de Fisher (2014), Rego (2003), Frank et al. (2009), Chen et al. (2010), a elisão fiscal das empresas é tratada como um dos itens de gestão, a fim de reduzir o lucro tributável por meio de atividades de planejamento tributário mediante interpretação da lei vigente, pagamento de imposto sobre os lucros declarados em um país diferente de onde eles foram gerados ou pagamento de impostos que ocorrem em tempo diferente em relação à obtenção dos lucros. Segundo Fisher (2014), os indivíduos que praticam a elisão fiscal, geralmente, dependem de brecha em torno da legislação tributária vigente, bem como de profissionais tributários que desejam explorar essas brechas na lei.

A partir da perspectiva de como a elisão fiscal pode ser percebida sob a ótica da sociedade, para Camargo (2009), ao longo do tempo a sociedade tem se mostrado mais exigente quanto ao posicionamento das empresas como agentes na redução de problemas sociais, por meio do desenvolvimento de projetos. A sociedade se atenta também quanto ao papel das empresas na transformação e distribuição de riquezas. 
A realidade é que ao passo que uma empresa, assim como um indivíduo, é capaz de definir suas próprias obrigações e políticas, direcionando esforços a fim de promover as suas finalidades, ela também é uma parte integrante da sociedade e demanda o seu apoio para sobreviver (ROBERTS, 1992).

Segundo Fisher (2014), a responsabilidade social é um conceito no qual, geralmente, as empresas decidem, em uma base voluntária, contribuir para uma sociedade mais justa. A partir da perspectiva da responsabilidade social corporativa, as organizações possuem dentre suas finalidades precípuas a de atuarem dentro das normas legais.

Conforme Freise et al. (2008), o pagamento dos tributos garante o financiamento dos bens públicos e das despesas da administração pública. Assim, as políticas de elisão fiscal de uma empresa podem ter um efeito negativo sobre a sociedade (FREEDMAN, 2003).

Lanis e Richardson (2011) afirmam que a elisão fiscal elaborada de forma organizada pode afetar a sociedade, considerando que os pagamentos dos impostos representam uma referencia para as alegações de responsabilidade social corporativa.

Fisher (2014) enfatiza que o principal argumento apresentado pelos defensores de responsabilidade social, sustentados na teoria dos stakeholders, é que a empresa não existe apenas para maximizar os lucros para os acionistas, mas também para servir a sociedade da qual depende para sua existência. Com base nesse pressuposto, a gestão das empresas não deve ser norteada apenas para o cumprimento de interesses dos proprietários, mas também por outros detentores de interesses, como exemplo, os trabalhadores, as comunidades locais, os clientes, os fornecedores, as autoridades públicas, os investidores, os colaboradores, os concorrentes e a sociedade.

A ideia de Responsabilidade Social Corporativa (RSC) continua a crescer em importância e significado desde os movimentos sociais iniciados na década de 1960. Desde então se procurou despertar o mundo e as empresas para a responsabilidade social que eles possuem, no sentido de que as mudanças fossem também promovidas para uma melhor consciência no mundo dos negócios (KARKOTLI; ARAGÃO, 2004).

As definições formais de RSC começaram a se expandir a partir da década de 1970, momento em que temas como responsabilidade e desempenho se tornaram o centro de discussões (CARROL; SHABANA, 2010). Conforme Souza et al. (2012), a partir da década de 1980, o movimento pela responsabilidade social das empresas tem adquirido um espaço maior, sobretudo, por meio de ações empresariais coletivas e de 
exposição na mídia. A iniciativa de uma empresa em se envolver em projetos voltados para o desenvolvimento social passa a ser mais valorizada pela sociedade, pelo governo e por seus investidores.

Carroll (1979) propõe um modelo para a performance social corporativa, incluindo quatro tipos de responsabilidade por parte das empresas (Figura 1): econômicas, legais, éticas e discricionárias (filantrópicas). A proposta de Carrol (1979), em estabelecer níveis de responsabilidade social, direciona em quais níveis da pirâmide a empresa deve se enquadrar sendo assim, o envolvimento social da empresa, seja com os empregados, com as pessoas que estão ligadas tecnicamente à empresa ou com a sociedade, deve avaliar muito bem esses aspectos, de modo que as empresas sejam lucrativas, obedeçam às leis, tenham comportamento ético e possam retribuir à sociedade em forma de ações discricionárias.

Figura 1 - Modelo para a performance social corporativa

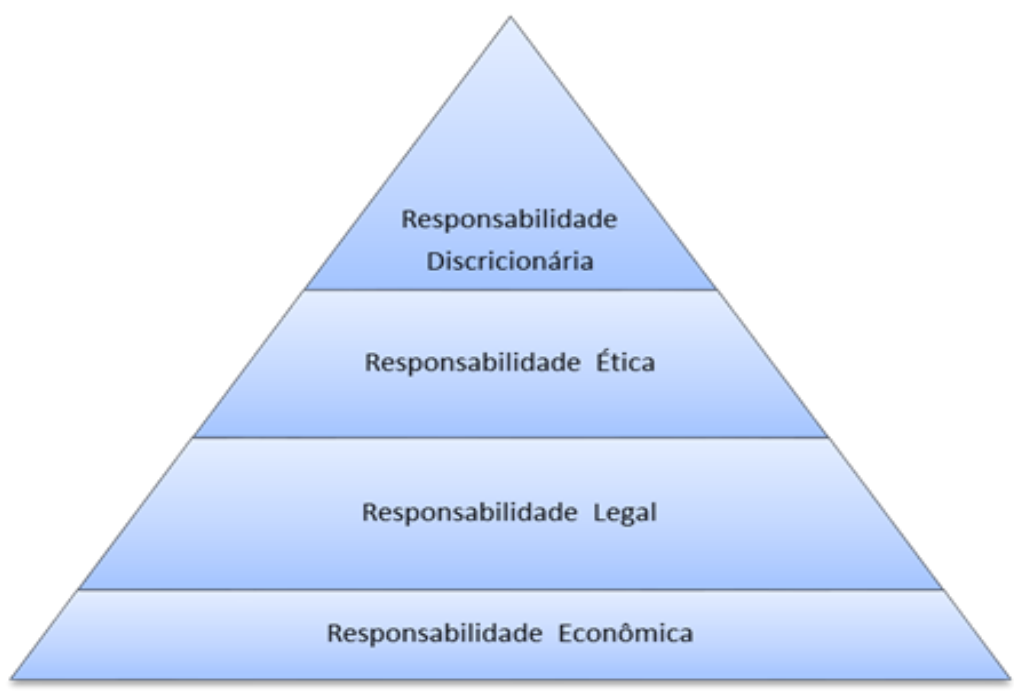

Fonte: Carrol (1979).

Segundo Souza et al (2012) embora haja uma crescente valorização das práticas de responsabilidade social, alguns estudiosos e profissionais (SUNDARAM; IKPEN, 2004; FRIEDMAN, 1970; ROBBINS; COULTER, 1998) criticam-na e consideram que a empresa não deve assumir uma responsabilidade social direta. A partir dessas considerações, evidencia-se uma discussão quanto ao fato de determinar até onde vai a responsabilidade das empresas, além de remunerar seus acionistas por meio do capital por eles investido. Porter e Kramer (2006) acreditam que a empresa é 
muito mais que um conjunto de contratos, tendo uma influencia significante não só com os acionistas. As empresas estão inseridas em ambientes, deparando-se com competitividade e negócios onde irão lidar com outras entidades e indivíduos. A partir da realidade em que está inserida, uma empresa desenvolve políticas, estratégias e operações, no intuito de buscar bons resultados, que irão lhe favorecer em seu ambiente de negócio.

Segundo Gonçalves (2006), há um conflito em que o gestor deve decidir entre a visão financeira de atender inicialmente os acionistas ou estabelecer como prioridade as demais partes interessadas. Essencialmente, as políticas, estratégias e operações não estarão centradas no acionista em si, mas serão responsáveis por outras partes (por exemplo, órgãos do governo, grupos políticos, sindicatos, comunidade, funcionários, fornecedores e clientes) e membros da sociedade como um todo. Sendo assim, as atividades voltadas para a responsabilidade social devem estar refletidas nas estratégias e principais operações de uma empresa como reconhecimento da sua responsabilidade para com a sociedade.

Friedman (1970) afirma, ainda, que destinar os recursos para causas sociais afetará diretamente o lucro das empresas, limitando os acionistas na decisão de como irão aplicar os referidos recursos. $O$ autor destaca também que só há uma responsabilidade social do capital, que é destinar os recursos a atividades que levem ao aumento de lucros, desde que permaneça dentro dos limites das regras. Isso significa "participar de uma competição livre e aberta sem enganos ou fraude" (p. 33).

A partir do exposto, nota-se que a adoção de práticas de responsabilidade social é influenciada por diferentes fatores, abordando diversos argumentos. Conforme Souza et al. (2012), deve-se considerar o funcionamento e a interação de todas as forças presentes na sociedade e alterações nas formas de organização das mesmas que geram impactos sobre a conduta cobrada e esperada da empresa.

Segundo Sancovschi et al. (2010), ao longo do tempo, as empresas estão direcionando esforços a projetos sociais (internos e externos ao meio empresarial) para reduzir as externalidades negativas provocadas por sua atividade operacional. Nota-se uma maior preocupação das empresas em manter uma boa reputação, a fim de se destacar no mercado. A partir desses fatores, Borger (2001) afirma que as empresas buscam melhorar o desempenho financeiro, social e ambiental e são encorajadas a procurar maneiras inovadoras de se relacionar com o ambiente social. Essa postura as leva a adotar estratégias para incrementar sua reputação. 
Contrapondo esta imagem voltada à responsabilidade social, Sikka (2013) enfatiza que grandes corporações estão produzindo relatórios contendo promessas de conduta socialmente responsável, porém, isso vem sendo acompanhado por práticas de evasão e elisão fiscal em grande escala. Ao partir do pressuposto de que o recolhimento de tributos gera receita para o Estado e que o mesmo repassa esses recursos à sociedade, Sikka (2013) acrescenta ainda que as receitas perdidas em função das práticas elisivas a fim de se reduzir os tributos são grandes e capazes de fazer a diferença para a qualidade de vida de milhões de pessoas.

A partir do papel desempenhado pelas empresas que adotam práticas voltadas à responsabilidade social, pode-se admitir a ideia de que essas empresas deveriam ter menores índices de elisão fiscal comparada às demais. A partir do que já foi exposto, verifica-se que as práticas de elisão fiscal de uma empresa podem ter um efeito negativo sobre a sociedade, o que reflete num comportamento contrário ao que é apresentado pelos conceitos de responsabilidade social. A partir do que foi apresentado, nota-se um conflito social inerente à própria natureza das corporações, que requerem reflexões sobre os mecanismos de elisão fiscal.

Através de suas ações sociais, ou seja, com a transferência voluntária de recursos para execução de projetos sociais e culturais para a comunidade onde atuam, as empresas buscam melhorar sua imagem e aumentar o seu valor, diminuir os riscos e aumentar suas vantagens em termos competitivos (MILANI FILHO, 2008; ORLITZKY; BENJAMIN, 2001; BROWN et. al., 2006).

No âmbito de ações sociais e seus benefícios, Heal (2005) afirma que responsabilidade social corporativa envolve tomar ações que reduzam o grau de custos externos ou evitar conflitos distributivos. O papel seria o de antecipar e minimizar os conflitos entre as corporações e os representantes da sociedade.

A adoção de um comportamento socialmente responsável habilita uma empresa a apresentar produtos diferenciados ao mercado (WADDOCK; GRAVES, 1997), capacita a empresa a evitar multas vultosas aplicadas por governos (SPICER, 1978; BELKAOUI, 1976) e, conforme Godfrey (2004), caracteriza uma ação que busca a redução da exposição de uma empresa a riscos.

Para Knuutinen (2014), as empresas devem tratar o cumprimento das obrigações fiscais como elemento importante para uma supervisão e gestão mais ampla dos riscos. Em particular, os conselhos de administração devem adotar estratégias de gestão de risco fiscal para assegurar que os riscos financeiros, regulamentares e de 
reputação associados à tributação, estão totalmente identificados e avaliados. Assim, segundo Teixeira e Nossa (2010), diante de um determinado nível de risco e de outros fatores constantes, um investidor teria razões para investir em empresas socialmente responsáveis visto que bancos ou instituições de crédito (credores) e investidores exigem, como pré-requisitos, garantias que estão fundamentadas nas características da empresa e levam em conta questões sociais nas decisões de investimento (SPICER, 1978).

Girão (2013) aponta que os investidores buscam investimentos disponíveis em mercados de capitais mais seguros. Essa insegurança está atrelada a percepção dos riscos assumidos pelo investidor que demanda por informações que lhes dê suporte para a avaliação destes riscos no processo de tomada de decisão (MUSSA et al, 1999). Seguindo a mesma linha, Gonçalves (2006) afirma que as boas práticas de responsabilidade social corporativa acarretam em qualidade das informações prestadas e reduzem as incertezas no processo de avaliação e, consequentemente, o risco.

Ao associar os riscos assumidos por determinadas práticas tributárias aos princípios de responsabilidade social corporativa, Knuutinen (2014, p. 46,) afirma que:

[...] várias atividades de responsabilidade social também podem ser vistas como útil para os acionistas. Este é talvez o argumento mais forte para a RSC, e também é o tipo de argumento aceito por quase todo mundo. Uma das tarefas de executivos da empresa é identificar e eliminar todos os tipos de riscos no negócio. A partir de hoje, uma falta na estratégia de RSC ou atividades relacionadas pode ser considerado um risco para o negócio e para a empresa. ${ }^{1}$

A partir de Knuutinen (2014), é possível afirmar que as práticas tributárias que levam ao aumento do risco por parte da empresa caminham de maneira contrária aos princípios das atividades socialmente responsáveis, que buscam exatamente reduzir ou eliminar todos os tipos de risco para o negócio.

Diante das discussões e conceitos apresentados, o litígio representa um risco para a empresa. Apesar das práticas de elisão serem ferramentas para obtenção de vantagens fiscais, embasadas nas incertezas e ambiguidades existentes nas normas, as empresas ao assumirem tais práticas assumem também riscos, que vão além do que se espera para uma empresa que goze de boa reputação. Segundo alguns autores, como Desai e Dharmapala (2006) e Fisher (2014), esses riscos incluem despesas processuais

\footnotetext{
${ }^{1}$ Moreover, several CSR activities can also be seen as useful for shareholders. This is maybe the strongest argument for CSR, and it is also the kind of argument almost everyone can ccept. One of the tasks of
} 
que surgirão em caso de litígio; custos financeiros, consequência das operações da empresa afetadas por danos à reputação; o relacionamento da empresa com os governos e as autoridades fiscais pode afetar sua futura participação em concorrências para os contratos públicos; a incerteza sobre futuras obrigações tributárias pode afetar o valor do acionista e a manipulação dos lucros e das contas associadas à elisão fiscal, que, geralmente, trata-se de ato errôneo por parte da administração da empresa, que deve conter esse tipo de prática.

Dessa forma, nota-se que, na percepção do mercado, e segundo alguns estudos (KURUCZ et al, 2008; BORGER, 2001; MILANI FILHO, 2008; ORLITZKY; BENJAMIN, 2001; BROWN et. al., 2006; HEAL, 2005; KNUUTINEN, 2014; GIRÃO, 2013; GODFREY, 2004; TEIXEIRA; NOSSA, 2010; BASSEN; MEYER; SCHLANGE, 2006) uma das razões que associa a tributação como uma questão de responsabilidade social das empresas, é o risco. Assim como questões sociais e ambientais, as práticas de elisão fiscal representam fator de risco para as empresas. Desta forma, as empresas socialmente responsáveis são consideradas de menor risco e as ações de elisão fiscal vão contra esta percepção.

\subsection{Responsabilidade social corporativa e elisão fiscal: estudos anteriores}

Os temas Elisão Fiscal (Tax Avoidance) e Responsabilidade Social Corporativa (RSC) estão inseridos em diversas disciplinas, inclusive, na literatura contábil. O interesse nessas áreas se deve aos tipos de usuários da informação contábil vinculados aos temas, sendo assuntos relativamente recentes. No Brasil, houve uma evolução no que tange à quantidade de pesquisas acerca da Responsabilidade Social Corporativa (RSC), devido, entre outros fatores, às exigências dos investidores em relação a informações mais transparentes sobre a gestão.

Pesquisas internacionais sobre a elisão fiscal passaram a despertar o interesse de alguns estudiosos, por exemplo, Shackelford e Shevlin (2001), Rego (2003), Tang (2006), Hanlon e Heitzman (2010) e Lanis e Richardson (2014).

Segundo Shackelford e Shevlin (2001) e Hanlon e Heitzman (2010), os impostos possuem natureza multidisciplinar, além de trazer diferentes linguagens e perspectivas. Sendo assim, o desenvolvimento de uma pesquisa empírica nessa área exige diferentes fontes de dados e, entre as disciplinas que trabalham as práticas tributárias, pode-se destacar a contabilidade, a economia, o direito e as finanças. 
Obviamente, o enfoque abordado em cada uma das pesquisas mencionadas é diferente, uma vez que economistas estão mais interessados na forma como as alíquotas afetam o investimento e o crescimento da economia. Em finanças, os estudos são, geralmente, em como os impostos afetam o valor da empresa, a política de decisões financeiras e o portfólio de decisão dos investidores (HANLON; HEITZMAN, 2010).

Pesquisas em adoção de perfil socialmente responsável foram encontradas como a de Diccico (2002). Em seu estudo, ao criticar o planejamento tributário afirma que o seu uso inadequado pode trazer impactos negativos na arrecadação tributária dos EUA.

O estudo de Lanis e Richardson (2011) sugere que os princípios da CSR (Corporate Social Responsibility) podem influenciar potencialmente a agressividade fiscal $^{2}$ de uma empresa, por meio do conselho de administração. Eles propõem que diretores externos são mais propensos a responder às necessidades da sociedade e, portanto, podem influenciar o conselho de administração a se distanciar da postura de elisão fiscal.

Lanis e Richardson (2012) desenvolveram uma pesquisa a fim de analisar se há associação entre a responsabilidade social corporativa (CSR) e agressividade dos impostos sobre as sociedades. Lanis e Richardson (2012) utilizaram taxas de imposto efetiva (ETR) como medidas para mensuração de elisão fiscal para uma amostra de 408 empresas australianas de capital aberto. A partir do estudo, descobriram que quanto maior o nível de divulgação da responsabilidade social, menor o nível de agressividade na tributação das empresas (em termos de taxas de imposto efetivas).

Hoi et al. (2013) realizaram um estudo semelhante, comparando práticas de elisão fiscal mais agressivas com práticas socialmente irresponsáveis (usando classificações sociais negativas). Eles descobriram que, quando as atividades contrárias ao comportamento que se considera socialmente responsáveis são excessivas, a probabilidade de práticas de elisão fiscal é maior.

O estudo de Huseynov e Klamm (2012), examinou o efeito de medidas de responsabilidade social, dentre elas a governança corporativa e a comunidade. Segundo os autores, ao separar os pontos fortes e as preocupações para cada medida de responsabilidade social, é possível analisar os efeitos socialmente positivos e negativos

\footnotetext{
${ }^{2}$ De acordo com pesquisas existentes (ver, por exemplo, Frank et al., 2009; Chen et al., 2010), define-se como agressividade fiscal a gestão a fim de reduzir o lucro tributável por meio de atividades de planejamento tributário.
} 
das ações envolvendo elisão fiscal. Dentre os resultados encontrados, foram apontadas evidências de que a responsabilidade social afeta as práticas de elisão fiscal a partir de uma divisão das empresas em carteiras com base nos níveis de RSC.

Knuutinen (2014) desenvolveu um artigo no intuito de revisar a responsabilidade social corporativa especialmente no contexto fiscal. A partir da sua discussão englobando a importância da responsabilidade social no contexto da legislação tributária o autor conclui que as práticas com impostos estão associadas à responsabilidade social corporativa. O autor afirma que as atitudes envolvendo impostos são muitas vezes contraditórias visto que por um lado, os impostos representam mais um custo dentre tantos outros que a empresa assume, mas por outro lado, são também uma contribuição econômica para a sociedade em que o negócio é conduzido.

O estudo de Teixeira e Nossa (2010) teve por objetivo averiguar se a forma de financiamento das empresas é afetada pela sua participação no índice de sustentabilidade empresarial (ISE) ${ }^{3}$ e se há relação entre o ISE e o risco (sistemático) de mercado. Os autores evidenciaram que as empresas que sinalizaram responsabilidade social corporativa (RSC) tiveram uma relação negativa com o endividamento e o risco, diferentemente do que ocorreu com as demais empresas. Isto permite afirmar que as empresas que sinalizaram RSC apresentam menor risco.

Estudos anteriores trazem evidências de que a adoção de RSC, por parte das empresas, como boas práticas sustentáveis e também como informação ao mercado, minimiza incertezas sobre as operações da empresa podendo influenciar na redução do risco e do custo de capital (BASSEN; MEYER; SCHLANGE, 2006; ORLITZKY; BENJAMIN, 2001).

\subsection{Indicadores de Elisão Fiscal}

Em estudo desenvolvido por Hanlon e Heitzman (2010), as medidas empíricas para cálculo da elisão fiscal foram estimadas, destacando as diferenças entre as formas de mensuração em conformidade ou não e avaliando os benefícios e as limitações de cada medida. Segundo os autores, a maioria das medidas de mensuração

\footnotetext{
${ }^{3}$ No estudo o ISE foi utilizado como proxy de sinalização admissível para o mercado, de empresas que são comprometidas com a RSC. A elaboração deste índice segue um padrão internacional dos principais índices de sustentabilidade do mundo (Dow Jones Sustainability Index - DJSI, Domini Social Index, FTSE4Good, índice de sustentabilidade da bolsa de Johanesburgo, etc.), dentro da dimensão triple bottom line.
} 
verificadas na literatura captura apenas a não conformidade da elisão fiscal, ou seja, operações contabilizadas de maneiras diferentes das alegadas nas declarações de imposto de renda. As medidas empíricas para cálculo da elisão fiscal estimadas por Hanlon e Heitzman (2010) estão demonstradas no Anexo A.

Segundo Cabello (2012), o fato da contabilidade societária ser diferente do exigido pela legislação tributária, é muito difícil coletar os dados nos demonstrativos contábeis para mensurar a elisão tributária. Segundo o autor, no Brasil, que apresenta na legislação situações, em que os tributos sobre o lucro possuem influência de valores extracontábeis, ou seja, aqueles valores que são mantidos apenas no Livro de Apuração do Lucro Real (LALUR) ou não são escriturados em contas de resultado, apenas em contas patrimoniais. O autor traz como exemplo de tais situações a depreciação acelerada incentivada, a compensação de prejuízos fiscais, as exclusões e adições por diferenças temporárias e incentivos fiscais.

A ETR ou Efetive Tax Rate é a primeira forma de mensuração da elisão tributária sugerida por Hanlon e Heitzman (2010), sendo apresentada sobre diversos enfoques (considerando lucro, fluxo de caixa, Generally Accepted Accounting Principles - GAAP ETR). A tabela elaborada pelas autoras, demonstrada no Anexo A, pode ser utilizada para uma melhor visualização das formas de mensuração da elisão tributária.

Conforme o Anexo A, o Generally Accepted Accouting Principles (GAAP) ETR é definido como o total das despesas totais com imposto de renda dividido pelo lucro contábil antes dos impostos (LAIR), não sendo afetado por uma estratégia fiscal que adia os impostos, mas por mudanças nas provisões ou reservas fiscais. O Cash ETR é calculado como os impostos pagos dividido pelo lucro contábil antes dos impostos e é afetado pelas estratégias de diferimento fiscal, mas não por mudanças nas provisões fiscais. No Anexo A, também é possível observar outras formas de mensuração da elisão fiscal por meio das ETRs, as quais não foram foco do presente estudo.

A Current Efetive Tax Rate (ETR) ou taxa efetiva dos tributos é calculada dividindo o imposto de renda por uma medida de lucro antes dos impostos. De acordo com as normas tributárias e contábeis brasileiras, o ERT seria calculado pela razão entre o Imposto de Renda da Pessoa Jurídica (IRPJ) somado à Contribuição Social sobre o Lucro Líquido (CSLL) pelo Lucro Antes do Imposto de Renda (LAIR) (SHACKELFORD; SHEVLIN, 2001; REGO, 2003; TANG, 2006; HANLON; HEITZMAN, 2010; LANIS; RICHARDSON, 2014). 
Pela proposta feita por Hanlon e Heitzman (2010), pode-se observar que a mensuração da ETR pode impactar ganhos contábeis, se o item não possuir diferença temporária. O objetivo, contudo, não está situado na análise dos ganhos contábeis, mas na utilização de práticas tributárias e seus efeitos na ETR.

A ERT corrente reflete estratégias de diferimento dos impostos, de acordo com as pesquisas de Lanis e Richardson (2012) e Rego (2003), e é adequada para indicar o planejamento tributário e, consequentemente, a elisão fiscal, pois um efetivo planejamento tributário resulta em baixas taxas de ETR corrente (TANG, 2003). Portanto, considerando duas empresas que possuem o mesmo LAIR, se uma delas possui uma menor despesa corrente com o imposto de renda, representa um ETR menor.

Segundo Rego (2003), a ETR corrente possui relação com o tamanho da empresa e o LAIR, pois maiores empresas possuem ETR correntes maiores e empresas com grande LAIR possuem ETR correntes menores.

Contudo, a capacidade do ERT pode ser limitada devido à exclusão dos tributos implícitos. Para Tang (2006, p. 5), "é difícil determinar se um baixo ETR é causado por benefícios fiscais ou práticas de diferimento. Assim, a proxy ETR pode introduzir erros de mensuração nos resultados de planejamento tributário". 4

Além disso, Hanlon e Heitzman (2010) ressaltam que apesar de todas as medidas de mensuração da ETR refletirem os efeitos sobre os impostos explícitos das empresas, elas não distinguem as práticas de elisão fiscal, ou seja, não há como afirmar que as reduções dos tributos foram decorrentes de estratégias de diferimento. Outro ponto levantado pelas autoras é a impossibilidade do ETR de capturar não conformidade da elisão fiscal, porque essas medidas de mensurações utilizam dados contábeis.

\subsection{Variáveis que explicam a Elisão Fiscal}

Cabello (2012) apresentou uma pesquisa sobre as escolhas das práticas contábeis voluntárias como indicadores de elisão fiscal na busca de redução dos tributos. Para fins da pesquisa o autor observou: i) métodos de depreciação (depreciação acelerada versus depreciação linear); ii) tratamento dos juros (ativo ou despesa); iii) avaliação de estoques (primeiro que entra é o primeiro que sai - PEPS ou o último que

\footnotetext{
4 "It is hard to ascertain whether the lower level of ETR is caused by tax preferences/holidays or tax sheltering. Thus, ETR proxy will introduce measurement error into the results of TM examination" (TANG, 2006, p. 5).
} 
entra é o primeiro que sai - UEPS); iv) tratamento dos créditos fiscais diferidos (diferido ou não diferido); v) custos de exploração de gás e óleo (full cost versus sucessfull efforts); vi) obrigações atuariais não cobertas (prazo de amortização); vii) arrendamento mercantil (capitalização ou não capitalização) e viii) método de conversão das demonstrações contábeis (corrente ou temporal).

Pohlmann e Iudícibus (2006) apresentam tax shelter como uma medida de planejamento tributário e destacam como exemplos: a adoção de depreciação acelerada; utilização de off-shores; o pagamento de juros sobre capital próprio; a realização de fusões e incorporações, buscando a redução da carga tributária.

Chaves (2010) sintetizou as medidas de planejamento tributário em: i) reconhecimento das perdas de créditos não liquidados; ii) Juros sobre Capital Próprio; iii) depreciação acelerada; iv) depreciação acelerada incentivada; e v) Incentivos Fiscais.

Pode haver um abuso por parte das empresas ao atribuir um valor para um determinado ativo que possui poucos marcadores ou referências que possam permitir uma comparação, o que resulta na perda de receita para o país residente. Atualmente, há uma dificuldade em se distinguir preço de transferência legal e ilegal e, consequentemente, de definir o que seria elisão fiscal (FISCHER, 2014).

Partindo do que foi exposto, pode-se elencar diversas escolhas contábeis tributárias que podem impactar a ETR (CABELLO, 2012; AARBU; MACKIEMASON, 2003; POHLMANN; IUDÍCIBUS, 2006; CHAVES, 2010; FREITAS ET AL, 2007; JANSSEN, 2005; FORMIGONI, 2008; PARANAIBA; MARQUES 2013; ALMEIDA, 2000; SCHOENELL ET AL, 2013; NETO ET. AL, 2015; SANTOS, 2007) as quais serão tratadas a seguir.

\subsubsection{Depreciação Acelerada e Depreciação Acelerada Incentivada}

Depreciação, conforme Fernandes (2011, p. 40), "representa a redução do potencial dos ativos em gerar benefícios. Tal redução é consequência da deterioração física do bem, desgaste por meio do uso, ou deterioração econômica por causa da obsolescência ou mudança na procura dos consumidores."

Conforme Freitas et al (2007, p. 258), “a variedade de metodologias para o cálculo da depreciação constitui num aspecto imprescindível para o estabelecimento de critérios específicos e mais compatíveis no cálculo do imposto de renda”. Existem 
vários métodos para o cálculo da depreciação, o que se justifica, uma vez que os equipamentos estão sujeitos a diferentes tipos de depreciação (física, funcional, acidental). O artigo 311 do Decreto 3.000 de 26 de março de 1999 (Regulamento do Imposto de Renda de 1999 - RIR/99) fixa critérios para cálculo da depreciação para fins de dedução na apuração do IRPJ como custo ou despesa operacional.

O tratamento da depreciação acelerada está regulamentado nos artigos 312 e 313 do RIR/99. Pelo regulamento, estão previstos a depreciação acelerada, em função do número de horas diárias de bens móveis, inclusive máquinas e veículos, e a depreciação acelerada, dada como um incentivo fiscal. Como uma prática tributária, a depreciação acelerada antecipa a despesa e, portanto, o imposto de renda, no momento da depreciação, será menor.

Para Freitas et al (2007), a depreciação acelerada ocorre nos casos em que, nos primeiros anos após o investimento, a depreciação é maior do que no método linear (normalmente adotado pelo governo). Entretanto, se a depreciação não se caracterizar como acelerada poderá, nessas condições, ocorrer uma subestimação da carga tributária, com um respectivo aumento do lucro por parte da empresa.

De acordo com Cabello (2012, p. 52), “a depreciação acelerada incentivada é a depreciação realizada sobre ativos adquiridos em certa época ou para integrar programas de estímulos industriais ou setoriais." Sendo assim, ativos semelhantes adquiridos em condições distintas podem sofrer depreciação com velocidade superior.

Conforme elencado no sítio da Receita Federal do Brasil, as formas de depreciação acelerada incentivada, prevista no artigo 313 do RIR, que podem ser utilizadas atualmente são:

a) Programas de Desenvolvimento Tecnológico Industrial (PDTI) e Programas de Desenvolvimento Tecnológico Agropecuário (PDTA) aprovados em 03/06/1993: as empresas industriais e agropecuárias, que executarem PDTI e PDTA, na forma do artigo 321 do RIR/1999, poderão promover depreciação acelerada, nas condições fixadas em regulamento, calculada pela aplicação da taxa de depreciação usualmente admitida, multiplicada por dois, sem prejuízo da depreciação normal das máquinas, equipamentos, aparelhos e instrumentos novos destinados à utilização nas atividades de pesquisa e desenvolvimento tecnológico, industrial e agropecuário. $\mathrm{O}$ benefício não poderá ser utilizado com outro da mesma natureza;

b) bens utilizados na atividade rural: os bens do ativo permanente imobilizado, exceto a terra nua, adquiridos por pessoa jurídica que explore a 
atividade rural, para uso nessa atividade, poderão ser depreciados integralmente no próprio ano da aquisição;

c) Dispêndios Realizados com Pesquisa Tecnológica e Desenvolvimento de Inovação Tecnológica de Produtos: a partir de 2003, os valores relativos aos dispêndios incorridos em instalações fixas e na aquisição de aparelhos, máquinas e equipamentos, destinados à utilização em projetos de pesquisa e desenvolvimentos tecnológicos, metrologia, normalização técnica e avaliação da conformidade, aplicáveis a produtos, processos, sistemas e pessoal, procedimentos de autorização de registros, licenças, homologações e suas formas correlatas, bem como relativos a procedimentos de proteção de propriedade intelectual, poderão ser depreciados na forma da legislação vigente, podendo o saldo não depreciado ser excluído na determinação do lucro real, no período de apuração em que concluída sua utilização.

A pesquisa desenvolvida por Freitas et al. (2007) buscou ilustrar um cenário de alternativas na cobrança de impostos, baseado em diferentes métodos de depreciação, tendo como referência a atividade de transporte florestal. A pesquisa apresentou o fluxo de caixa calculado antes e depois dos impostos, sendo esses determinados com base em um percentual incidido sobre a renda tributável, que variou em função das metodologias utilizadas no cálculo da depreciação. A metodologia adotada no estudo indicou que o método adotado pelo governo pode acarretar sobrecarga tributária. Isso reflete a necessidade de se estabelecerem critérios mais justos na cobrança de impostos, por meio da adoção de metodologias mais adequadas às realidades dos equipamentos.

\subsubsection{Juros sobre Capital Próprio}

O conceito de juros sobre o capital próprio, do ponto de vista teórico, inserese no conceito mais amplo de custo de oportunidade, que tem suas origens no campo da economia. Segundo Burch e Henry (1974), o conceito de custo de oportunidade se originou com Frederich Von Weiser que o utilizou para definir o valor de um fator de produção.

O tema Juros sobre o Capital Próprio pode ser pesquisado sobre alguns ângulos, destacando-se que a expressão "juros sobre o capital próprio" tem sido utilizada como algo que substitui o "custo do capital próprio" ou "custo de oportunidade". 
Na literatura contábil, a definição de custo de oportunidade vem sempre atrelada à hipótese de melhor alternativa que foi deixada de lado ou desprezada. Isso pressupõe que a aplicação de tal conceito exigirá a existência de duas ou mais alternativas possíveis e que sejam excludentes

O custo do capital próprio normalmente é definido pelo retorno que é esperado pelos investidores (sócios ou acionistas), em relação aos recursos por eles aplicados em determinados empreendimentos (ABDELGHANY, 2005).

Com o advento do Plano Real, em 1996 no Brasil, encerrou-se um longo período de correção monetária nas demonstrações financeiras das empresas. Em substituição, foi constituída a figura dos juros sobre o capital próprio (JSCP), a partir da promulgação da Lei 9.249/95, criando a possibilidade das empresas remunerarem seus acionistas por meio do pagamento de JSCP.

A Lei estabelece que o que os pagamentos efetuados a esse título sejam considerados como despesas dedutíveis no cálculo do imposto de renda e da contribuição social incidentes sobre os lucros das empresas e o efetivo pagamento ou crédito dos juros fica condicionado à existência de lucros computados antes da dedução dos juros ou lucros acumulados, ou reserva de lucros, em montante igual ou superior a duas vezes os juros a serem pagos ou creditados.

A regulamentação dos JSCP consta no artigo 347 do RIR/1999, incluído pela Lei 9.249 de 1995, artigo $9^{\circ}$. A norma legal institui a dedutibilidade das importâncias pagas ou creditadas aos sócios ou acionistas das pessoas jurídicas a título de juros sobre o capital próprio. O artigo 347 (RIR/99) descreve qual a regra para dedutibilidade dos JSCP:

Art. 347. A pessoa jurídica poderá deduzir, para efeitos de apuração do lucro real, os juros pagos ou creditados individualizadamente a titular, sócios ou acionistas, a título de remuneração do capital próprio, calculados sobre as contas do patrimônio líquido e limitados à variação, pro rata dia, da Taxa de Juros de Longo Prazo - TJLP (Lei n ${ }^{\circ}$ 9.249, de 1995, art. $9^{\circ}$ ).

$\S 1^{\circ} \mathrm{O}$ efetivo pagamento ou crédito dos juros fica condicionado à existência de lucros, computados antes da dedução dos juros, ou de lucros acumulados e reservas de lucros, em montante igual ou superior ao valor de duas vezes os juros a serem pagos ou creditados (Lei $\mathrm{n}^{\circ} 9.249$, de 1995 , art. $9^{\circ}, \S 1^{\circ}$, e Lei $\mathrm{n}^{\circ}$ 9.430, de 1996, art. 78).

$\S 2^{\circ}$ Os juros ficarão sujeitos à incidência do imposto na forma prevista no art. 668 (Lei ${ }^{\circ} 9.249$, de 1995, art. $9^{\circ}, \S 2^{\circ}$ ).

$\S 3^{\circ} \mathrm{O}$ valor dos juros pagos ou creditados pela pessoa jurídica, a título de remuneração do capital próprio, poderá ser imputado ao valor dos dividendos de que trata o art. 202 da Lei $n^{\circ} 6.404$, de 1976, sem prejuízo do disposto no $\S 2^{\circ}\left(\right.$ Lei n ${ }^{\circ} 9.249$, de 1995, art. $\left.9^{\circ}, \S 7^{\circ}\right)$. 
$\S 4^{\circ}$ Para os fins de cálculo da remuneração prevista neste artigo, não será considerado o valor de reserva de reavaliação de bens ou direitos da pessoa jurídica, exceto se esta for adicionada na determinação da base de cálculo do imposto de renda e da contribuição social sobre o lucro líquido (Lei nº 9.249, de 1995, art. $9^{\circ}, \S 8^{\circ}$ ) (BRASIL, 1999).

A Comissão de Valores Mobiliários (CVM) reconhece o pagamento de JSCP como distribuição de lucros e não como despesa financeira. Segundo a Deliberação 207 de 1996, as companhias abertas devem registrar o valor líquido dos JSCP (excluindo o imposto de renda) na conta de lucros acumulados, sem afetar o resultado do exercício, sendo utilizada apenas para a dedução do IRPJ e da CSLL. Esse procedimento consiste no estorno dos JSCP após a apuração do lucro líquido, retornando, portanto, o valor escriturado como despesa financeira.

Segundo Schoenell et al (2013), a remuneração aos acionistas por meio dos JSCP é uma alternativa no planejamento tributário, uma vez que é decisão da empresa escolher a melhor maneira de remunerar os sócios.

Neto et. al. (2015), buscaram analisar e descrever como as maiores empresas de capital aberto do mercado brasileiro distribuíram seus resultados no exercício de 2013 abarcando o conflito de agência e as práticas de planejamento tributário. No estudo, foi feita comparação dos critérios adotados e a política de distribuição de lucros, tanto na modalidade de dividendos quanto na forma de juros sobre capital próprio (JSCP), por tipo de acionistas, quer sejam pessoas físicas ou jurídicas. A partir dos resultados, os autores perceberam como a legislação tributária teve relevante influência na tomada de decisão, no que se refere à remuneração de seus acionistas. Sobre o total da remuneração realizada encontrada pelo estudo, constatou-se que apenas $37 \%$ se deu por meio de JSCP, percentual justificado pela própria limitação imposta pela legislação vigente, e o fato de o controle acionário das empresas em estudo ser consideravelmente exercido por outras pessoas jurídicas

Santos (2007) procurou responder algumas questões a partir de um estudo realizado em empresas do banco de dados da Revista Exame Melhores e Maiores. As questões levantadas pelo autor estavam relacionadas com o pagamento de JSCP aos sócios/acionistas de modo a comparar o pagamento dos mesmos entre empresas estrangeiras, estatais e nacionais. O autor também comparou o pagamento de JSCP entre empresas abertas e fechadas contemplando o período 1995 a 2005. De acordo com o estudo, $42 \%$ das empresas utilizaram os JSCP destacando equilíbrio entre o número de indústria, comércio e prestação de serviço. 


\subsubsection{Incentivos Fiscais Federais}

Considerando o perfil e objetivos traçados nesta pesquisa, serão levados em consideração apenas os incentivos fiscais federais que impactam no IRPJ e na CSLL. Os incentivos fiscais regionais e de outros tributos federais não serão objeto de coleta e análise, uma vez que esses podem distorcer os resultados. São exemplos dos tributos não considerados: Programa de Integração Social (PIS), Contribuição para o Financiamento da Seguridade Social (Cofins), Imposto sobre Produtos Industrializados (IPI) e Imposto de Importação e Exportação.

Segundo Paranaiba e Marques (2013, p. 20), "ao tratar dos incentivos ou benefícios de natureza tributária, é importante perceber que nem todo benefício fiscal é um benéfico tributário."

De acordo com Cabello (2012, p. 64) "não existe consenso em algumas diferenciações, em termos jurídicos, de renúncia fiscal, benefício fiscal e incentivo fiscal." O autor traz como exemplos de benefícios: anistia e parcelamento, já os de incentivos: isenção ou redução da base de cálculo ou dedução dos tributos apurados.

Consta nos Art. 165 da Constituição Federal/88 e Art. 14 da LC 101/2000 que as práticas de benefícios fiscais são: isenção, anistias, remissões, subsídios, créditos presumidos, alterações de alíquotas e mudanças na base de cálculo.

Para Paranaiba e Marques (2013) os benefícios tributários que são considerados incentivos físcais são aqueles que promovem uma indução do comportamento dos agentes econômicos que se sujeitam a eles.

Trazendo a definição, tem-se que incentivo fiscal é o benefício tributário que "estimule os agentes a agirem de determinada forma, objetivando a atingir um alvo econômico ou social previamente definido" (ALMEIDA, 2000, p.28).

Conforme Formigoni (2008, p. 28):

de forma geral, o que há em comum entre benefício e incentivo fiscal é que ambos são pertencentes à matéria tributária, no entanto o primeiro é concedido para resolver resultados danosos passados, enquanto o segundo objetiva criar resultados positivos futuros.

Ainda segundo Formigoni (2008, p. 14), o incentivo fiscal deve ser visto como objeto de financiamento da atividade principal da empresa:

O incentivo fiscal pode ser visto como uma fonte de financiamento para a empresa na medida em que, deixando de recolher os impostos, pode aplicar 
esses recursos em outros ativos ou processos ligados à sua atividade principal com o objetivo de obter um melhor desempenho econômico e financeiro.

Cabello (2012,) elencou os incentivos fiscais, que impactam o IRPJ e a CSLL, disponíveis para as empresas com opção pelo Lucro Real em:

a) Fundo de Investimento na Amazônia (Finam) ou Fundo de Investimento do Nordeste (Finor) e Fundo de Recuperação Econômica do Estado do Espírito Santo (FUNRES), que está regulamentado pelo Decreto $\mathrm{n}^{\circ} 2.259$ de 1997, conforme segue:

As pessoas jurídicas que, por força do art. $9^{\circ}$ da Lei $n^{\circ} 8.167$, de 16 de janeiro de 1991, tenham assegurado a aplicação, em projetos próprios, de recursos decorrentes do valor de suas opções pela aplicação do imposto de renda no FINAM, FINOR ou FUNRES poderão destinar, mediante indicação, no Documento de Arrecadação de Receitas Federais - DARF, do código de receita exclusivo do fundo ou dos fundos beneficiários, uma parcela do imposto sobre a renda das pessoas jurídicas, pago por estimativa, de valor equivalente a até:

I - $24 \%$, para o FINAM ou FINOR;

II - 33\%, para o FUNRES (BRASIL, 1997).

b) Fomento das atividades de caráter desportivo, regulamentando pelo

Decreto $\mathrm{n}^{\circ} 6.180$ de 2007, conforme segue:

A partir do ano-calendário de 2007 e até o ano-calendário de 2015, inclusive, poderão ser deduzidos do imposto de renda devido, apurado na declaração de ajuste anual pelas pessoas físicas ou em cada período de apuração, trimestral ou anual, pela pessoa jurídica tributada com base no lucro real os valores despendidos a título de patrocínio ou doação, no apoio direto a projetos desportivos e paradesportivos previamente aprovados pelo Ministério do Esporte.

As deduções de que trata o caput ficam limitadas:

I - relativamente à pessoa jurídica, a um por cento do imposto devido, observado o disposto no $\S 4^{\circ}$ do art. $3^{\circ}$ da Lei $\mathrm{n}^{\circ} 9.249$, de 26 de dezembro de 1995, em cada período de apuração;

$\S 2^{\circ}$ As pessoas jurídicas não poderão deduzir os valores de que trata o caput para fins de determinação do lucro real e da base de cálculo da Contribuição Social sobre o Lucro Líquido - CSLL (BRASIL, 2007).

c) Projeto destinado à Superintendência de Desenvolvimento da Amazônia (Sudam) e Superintendência do Desenvolvimento do Nordeste (Sudene), regulamentado pelo Decreto ${ }^{\circ} 6.539$ de 2008, conforme segue:

As pessoas jurídicas que tenham projeto protocolizado e aprovado a partir do ano-calendário de 2000 até 31 de dezembro de 2013 para instalação, ampliação, modernização ou diversificação, enquadrado em setores da economia considerados, em ato do Poder Executivo, prioritários para o desenvolvimento regional nas áreas de atuação da Superintendência do Desenvolvimento da Amazônia - SUDAM e da Superintendência do 
Desenvolvimento do Nordeste - SUDENE, terão direito à redução de setenta e cinco por cento do imposto sobre a renda e adicional, calculados com base no lucro da exploração (BRASIL, 2008).

d) Programa de Alimentação do Trabalhador (PAT), em que podem ser deduzidos, do IRPJ a pagar, 15\% das despesas de custeio do PAT, líquidas da parcela cobrada dos trabalhadores, ou $\mathrm{R} \$ 0,30$ multiplicado pelo número de refeições fornecidas no ano, prevalecendo o valor que for menor. No entanto, não pode exceder o limite de $4 \%$ do IRPJ a pagar;

e) Programas de Desenvolvimento Tecnológico Industrial ou Agropecuário (PDTI/ PDTA) aprovados após 03.06.1993, onde 15\% dos dispêndios incorridos em atividades de pesquisa e de desenvolvimento tecnológico industrial ou agropecuário, de acordo com o programa previamente aprovado, podem ser deduzidos em até $4 \%$ do imposto de renda devido;

f) Doações e patrocínios culturais realizados em favor de projetos previamente aprovados pelo Ministério da Cultura e de acordo com o Programa Nacional de Apoio à Cultura (Pronac) ou doações e patrocínios diretos, ao Fundo Nacional da Cultura (FNC). A dedução permitida tem como base $40 \%$ das doações e $30 \%$ dos patrocínios e a dedução não pode exceder $4 \%$ do imposto;

g) Doações aos Fundos dos Direitos da Criança e do Adolescente podem ser deduzidas em até $1 \%$ do imposto de renda devido, vedada a dedução da doação como despesa operacional;

h) Bônus de adimplência fiscal, instituído pela Lei 10.637/2002, que corresponde a uma dedução de $1 \%$ na CSLL devida, concedido a pessoa jurídica que, nos últimos 5 (cinco) anos-calendário, não se enquadre em qualquer das seguintes hipóteses, em relação a tributos e contribuições administrados pela Secretaria da Receita Federal:

i. lançamento de ofício;

ii. débitos com exigibilidade suspensa;

iii. inscrição em dívida ativa;

iv. recolhimentos ou pagamentos em atraso; ou

v. falta ou atraso no cumprimento de obrigação acessória.

Tomando como base estudos anteriores (LANIS; RICHARDSON, 2014; HUSEYNOV; KLAMM, 2012; CABELLO, 2012), é possível verificar que além das 
práticas tributárias, existem outros fatores que possuem certa associação com as práticas de elisão fiscal sendo assim influenciam na determinação da ETR de uma empresa. Tais fatores serão apresentados a seguir.

\subsubsection{Idade de oferta pública da ação}

O tempo ou idade de oferta pública da ação (IDP) representa o período temporal que as ações de uma corporação estão negociadas em mercados públicos (LOEBBECKE et al., 1989).

De acordo com o American Institute of Certified Public Accountants (AICPA, 1987), é possível que empresas mais recentes no mercado de capitais corram um risco muito maior de delito financeiro, devido à gestão ser obrigada a atender às expectativas de ganhos. Beasley (1996) afirma que quanto mais tempo uma empresa possui suas ações negociadas em bolsa, é provável que tenha feito alterações para cumprir exigências de mercado.

Segundo pesquisa feita por Lanis e Richardson (2011), a previsão foi de que a variável representativa do tempo em que a empresa oferta suas ações em mercados públicos tivesse sinal negativo em relação à medida de elisão físcal (ETR). Sendo assim, os autores esperavam que as empresas mais recentes no mercado apresentassem menores práticas de elisão fiscal. Foi constatado segundo o estudo, que quanto mais tempo a empresa está negociada em mercados públicos, maior a probabilidade de elisão fiscal.

\subsubsection{Serviços de auditoria}

Segundo Lanis e Richardson (2013) a contratação de empresas de auditoria bem conceituadas junto ao público, no caso as chamadas Big Four (as quatro maiores), é fator determinante na divulgação de informações, pois seus trabalhos transmitem maior credibilidade aos usuários pelo fato de serem mais conceituadas.

Conforme Rezaee (2005) os serviços de auditoria representam um papel relevante na evidenciação de informações, pois são mais exigentes. As big-four por serem empresas de grande porte chamam mais atenção e são reconhecidas internacionalmente, o que eleva o risco de enfrentar litígios. 
Utilizar como serviços de auditoria uma entre as quatro maiores empresas contábeis especializadas em auditoria e consultoria do mundo (big-four) ${ }^{5}$ pode significar a redução de práticas de elisão fiscal, por meio de um controle reforçado e de uma auditoria de qualidade superior.

Pesquisas anteriores (MATSUMURA; TUCKER, 1992; REZAEE, 2005; WALLACE E NASER 1996) encontraram uma associação positiva entre o envolvimento com uma das big four, a percepção da qualidade da auditoria e a detecção de fraudes de demonstrações financeiras. Assim, espera-se que os clientes de uma das quatro maiores empresas em auditoria apresentem menos elisão fiscal.

\subsubsection{Tamanho da empresa}

Para Watts e Zimmerman (1986) grandes empresas estão em maior evidência e atenção de órgãos reguladores, entidades de classe, impressa, ambientalistas, grupos de defesa dos consumidores, dentre outros. Segundo o autor, há uma associação entre tamanho e alavancagem, exploração de mão de obras, sonegação de impostos, degradação do meio ambiente, preços abusivos, etc. Neste sentido, RiahiBelkaoui e Karpik (1988) afirmam que as empresas tendem a aperfeiçoar suas práticas de divulgação como um mecanismo para a redução da assimetria informacional e contornar este problema.

Partindo do pressuposto de que as grandes empresas possuem mecanismos mais robustos para preparação e elaboração dos relatórios, dentre eles uma quantidade significativa de recursos, mão de obra especializada, departamentos próprios que permitem a produção de melhores informações, mais pessoas envolvidas no processo de coleta e organização das informações, enquanto as pequenas empresas não dispõem de estrutura e recursos, pois com poucas pessoas envolvidas no processo de coleta e organização das informações não conseguem reuni-las na mesma quantidade e qualidade, aumentando assim o custo de propriedade, e neste sentido espera-se que os custos de preparação e elaboração dos relatórios para empresas maiores sejam reduzidos (DIAMOND, 1985; LANG; LUNDHOLM, 1993; DEPOERS, 2000; ADAMS, 2002; LEUZ; WYSOCKI, 2008).

\footnotetext{
${ }^{5}$ PricewaterhouseCoopers, Deloitte Touche Tohmatsu, KPMG e Ernst \& Young.
} 
As empresas consideradas de grande porte estão expostas a maiores exigências pelos órgãos reguladores, possuem maior custo político por estarem em maior evidência que as médias e pequenas empresas, e os analistas de mercado tendem a um interesse maior nestas empresas, e tendem a divulgar mais informações voluntárias desejando aumentar sua reputação e reduzir custos, e ainda suprir a demanda por informações (TROTMAN; BRADLEY, 1981; WATTS; ZIMMERMAN, 1986; LANG, LUNDHOLM, 1993; WALLACE; NASER, 1996).

Com base na pesquisa acerca de elisão fiscal desenvolvida por Richardson e Lanis (2012) espera-se que as corporações de grande porte sejam mais tendenciosas às práticas de elisão fiscal considerando que possuem maior poder econômico e político em relação a empresas menores.

Seguindo a mesma linha, Zimmerman (1983), afirma que as grandes empresas são mais tendenciosas a tentarem se esquivar ou reduzir os tributos quando comparadas a empresas menores. Empresas de grande porte além de apresentarem maior poder político e econômico, apresentam mecanismos mais robustos para preparação e elaboração dos relatórios o que facilita e as deixam mais capazes de reduzir os seus encargos fiscais em conformidade com a lei.

\section{PROCEDIMENTOS METODÓLOGICOS}

\subsection{Natureza e Tipo de Pesquisa}

A natureza da pesquisa é qualitativa e quantitativa uma vez que os itens referente às práticas tributárias, adoção de auditoria e certificação pelo ISE foram extraídos a partir do uso da técnica da análise de conteúdo das demonstrações contábeis. (RICHARDSON et al. 1999).

Tuckman (2005) utiliza o termo análise crítica da bibliografia para definir a

revisão da literatura. É a primeira parte do processo de pesquisa, sendo essencial para definir se o assunto já havia sido tratado anteriormente, quais os conceitos que foram utilizados, quais as metodologias adotadas e os resultados alcançados (BILHIM; AMARO; MOREIRA, 2010). Em virtude de poucos estudos sobre o tema no Brasil, a análise documental estrangeira foi predominante durante o processo de investigação, a fim de caracterizar o objeto de estudo e estabelecer a metodologia mais adequada. 
A segunda etapa é o modo em que os dados foram tratados. Nesta pesquisa, utilizou-se o método quantitativo, pois corresponde a análise das demonstrações financeiras e do tratamento dos dados por meio de testes estatísticos. A triangulação da informação, ou seja, a combinação de múltiplas práticas metodológicas, materiais empíricos e perspectivas em um mesmo estudo (DENZIN, 2000) é um plano de ação que visa reduzir o viés característico do uso de apenas um método.

Segundo Richardson et. al. (1999, p.70) o método quantitativo é "frequentemente aplicado nos estudos descritivos e naqueles que procuram descobrir e classificar a relação entre variáveis, bem como, nos que investigam a relação de causalidade entre fenômenos".

A pesquisa possui finalidade aplicada uma vez que buscou analisar se a adoção de responsabilidade social corporativa está associada à prática de elisão físcal. Os dados coletados são de origem documental e foram obtidos a partir das Demonstrações Financeiras Publicadas, extraídas do sítio da BM\&FBOVESPA, legislação tributária e base de dados da Economática®. Quanto à tipologia, a pesquisa é considerada descritiva. Conforme Gil (1996) pesquisas descritivas apresentam como objetivo a descrição das características de determinada população ou a determinação de relações entre as variáveis. Considerando que é apresentado a ETR e os demais dados no período de 2009 a 2013 nota-se dados coletados para cada empresa em diversos anos o que permite afirmar que a pesquisa possui aspecto longitudinal que segundo Hair et al. (2005, p.88) é caracterizado por dados "coletados das mesmas unidades da amostra em diversos pontos no tempo", representando uma série temporal de observações.

\subsection{Objeto de estudo}

A partir das pesquisas apontadas no referencial teórico, em princípio as empresas socialmente responsáveis geram valor para o acionista em longo prazo, pois estão mais preparadas para enfrentar riscos econômicos, sociais e ambientais. A procura de investidores por esse tipo de empresas vem se fortalecendo ao longo dos anos e vários órgãos financeiros internacionais têm atendido essa demanda, por meio da divulgação de índices de responsabilidade social (BM\&FBOVESPA, 2010).

Este estudo possui como objetivo examinar se as práticas de responsabilidade social corporativa estão associadas à uma menor prática de elisão 
fiscal. O fato de procurar validar uma hipótese científica, utilizando técnicas estatísticas, caracteriza a pesquisa como empírico-analítica (MARTINS, 2002).

No Brasil especificamente, existem poucos índices que avaliem os critérios de conformidade em Responsabilidade Social. O ISE é reconhecido como indicador da sustentabilidade corporativa, caracterizando a valorização das empresas que, em tese, são as mais sustentáveis do país (MARCONDES; BACARJI, 2010).

Em 2005, a BM\&FBOVESPA, com o apoio de diversas outras instituições, lançou o Índice de Sustentabilidade Empresarial (ISE), sendo o primeiro indicador do tipo na América Latina e o quarto do mundo com o objetivo de mostrar o desempenho de mercado de uma carteira formada por empresas que adotam os princípios de gestão sustentável. A intenção é que o índice fosse um benchmark para os investidores socialmente responsáveis, além de estimular outras empresas a incorporar questões ambientais, sociais e de governança aos processos de decisão.

Segundo Marcondes e Bacarji (2010), o ISE foi uma construção multistakeholder, que gerou consistência e credibilidade, não só pelos resultados apresentados, mas também pelo processo participativo e transparente com que foi desenvolvido.

O ISE tem objetivo de refletir o retorno de uma carteira de ações de empresas sustentáveis empresarialmente e comprometidas com a responsabilidade social, além de atuar como fomentador das boas práticas no Brasil (BM\&FBOVESPA, 2010).

Por ser uma ferramenta para análise comparativa do desempenho das empresas sob o aspecto da sustentabilidade corporativa, baseada em eficiência econômica, equilíbrio ambiental, justiça social e governança corporativa, o ISE foi utilizado como base na formação da amostra desta pesquisa. A fim de testar empiricamente a hipótese central, foi tomado como base as empresas listadas na BM\&FBOVESPA que estão certificadas no Índice de Sustentabilidade Empresarial (ISE)

A escolha pelo Índice de Sustentabilidade Empresarial (ISE) ocorreu pela existência de poucos índices que avaliem os critérios de conformidade em Responsabilidade Social das empresas no Brasil. Sendo assim, foi necessário encontrar um índice reconhecido mundialmente e que possuísse uma carteira de empresas grande o suficiente para compor uma amostra de pesquisa. 


\subsubsection{População e amostra}

A população-alvo desta pesquisa é formada por empresas abertas do Brasil, e toma como referencia os dados dos anos de 2009 a 2013, extraídos do endereço eletrônico da BM\&FBOVESPA e Economática®.

No que se refere à amostra de pesquisa, Lakatos e Marconi (2001) definem que existem dois tipos de amostragem: não probabilística e probabilística. A primeira caracteriza-se pelo não emprego de procedimentos aleatórios de seleção, não podendo ser objeto de certos tipos de tratamento estatístico. A segunda é estabelecida pela escolha aleatória dos pesquisados, em que a seleção se faz de forma que cada um deles tenha a mesma probabilidade de ser escolhido. Esta pesquisa apresentou amostra não probabilística composta por empresas abertas do Brasil que compõem as carteiras do Índice de Sustentabilidade Empresarial (ISE). Para todas as empresas que compõe a carteira dentro do período de 2009 a 2013 foram identificadas o total de 187 observações.

Além das informações de empresas que compõem o ISE (ANEXO B), foram utilizados os dados publicados por empresas listadas na BM\&FBOVESPA e que não compõem a carteira do ISE (denominadas não certificadas pelo ISE). Para formação do grupo de controle, foi estabelecida uma comparação a partir do ativo total e do ramo de atividade de cada empresa que é certificada pelo ISE com as empresas que não são certificadas. Desta forma, cada empresa que compôs a amostra por compor a carteira, possui uma empresa semelhante correspondente (de acordo com os critérios acima mencionados) passível de comparação, o que definiu o total de 374 observações durante a série temporal de cinco anos. As empresas denominadas como não certificadas pelo ISE compõe a amostra e estão listadas no anexo $\mathrm{C}$ deste estudo, denominadas como grupo de controle.

Em virtude dos objetivos do estudo e das limitações dos indicadores de elisão fiscal, foram excluídas:

i. instituições financeiras, em razão de a legislação tributária possuir tratamento diferenciado dessas empresas em relação às demais, o que pode acarretar em práticas tributárias e impactos diferentes, afetando as ETRs de maneira diferente do que as outras empresas; 
ii. empresas com ETR inferior a 0, pois valores anormais podem interferir nos resultados da análise.

Por fim, a amostra final resultou em um total de 72 empresas, com 180 observações para o grupo de empresas listadas no ISE e para o grupo de controle de empresas não listadas perfazendo o total de 360 observações para todas as empresas dentro do período de 2009 a 2013, como pode ser observado na tabela a seguir:

Tabela 1- Empresas componentes da pesquisa ao final de cada ano

\begin{tabular}{c|c|c|c|c|c}
\hline Ano & 2009 & 2010 & 2011 & 2012 & 2013 \\
\hline Quantidade & 44 & 48 & 48 & 44 & 48 \\
\hline
\end{tabular}

Quanto à distribuição das empresas em relação ao setor, foram identificados a partir da classificação proposta pelo sistema Economática ${ }^{\circledR} 17$ setores conforme demonstrado no quadro a seguir:

Quadro 1- Quantidade de empresas por setor

\begin{tabular}{|l|c|}
\hline SETOR DE ATIVIDADE & No de empresas \\
\hline Abatedouros & 2 \\
\hline Administração de empresas e empreendimentos & 2 \\
\hline Agua, esgoto e outros sistemas & 4 \\
\hline Atividades auxiliares ao transporte rodoviário & 4 \\
\hline Comércio atacadista de bens não duráveis variados & 2 \\
\hline Construção de edifícios residenciais & 2 \\
\hline Bens Industriais, máquinas e equipamentos & 2 \\
\hline Geração, transmissão e distribuição de energia elétrica & 22 \\
\hline Indústria de autopeças, equipamentos aeroespacias & 2 \\
\hline Indústria de máquinas industriais & 2 \\
\hline Indústria de móveis, produtos de madeira compensada e afins & 2 \\
\hline Indústria de papel, celulose e papelão & 6 \\
\hline Indústria química & 2 \\
\hline Mineração de metais & 2 \\
\hline Serv.Méd.Hospit..Análises e Diagnósticos & 4 \\
\hline Telecomunicações & 6 \\
\hline Transformação de aço em produtos de aço, fundição & 6 \\
\hline TOTAL & $\mathbf{7 2}$ \\
\hline
\end{tabular}

As práticas tributárias se restringem às que decorrem de escolhas contábeis e se relacionam à tributação do lucro no Brasil, as quais, de acordo com a legislação 
brasileira, referem-se especificamente ao IRPJ e à CSLL, não abrangendo, portanto, outros tributos.

Mediante o que já foi exposto, e segundo outros estudos como o de Cabello (2012) pode-se afirmar que existem diversas escolhas contábeis tributárias que podem impactar a ETR das empresas dentre elas: depreciação acelerada, depreciação acelerada incentivada, juros sobre o capital próprio, reorganização societária, incentivos fiscais federais, preço de transferência, método de avaliação do estoque, reconhecimento das perdas de créditos não liquidados, utilização de offshore.

A limitação em relação à seleção de variáveis surgiu mediante uma préanálise (análise de conteúdo) efetuada nas Demonstrações Financeiras Publicadas. Diante da busca por palavras-chave estabeleceu-se que não é possível analisar os efeitos de todas as práticas tributárias na ETR, pois não são mencionadas nas Demonstrações Financeiras.

Considerando as limitações impostas pela possibilidade de identificar determinadas informações em demonstrações, as práticas tributárias que serão objeto desta pesquisa são (CABELLO, 2012; AARBU; MACKIE-MASON, 2003; POHLMANN; IUDÍCIBUS, 2006; CHAVES, 2010; FREITAS ET AL, 2007; JANSSEN, 2005; FORMIGONI, 2008; PARANAIBA; MARQUES 2013, ALMEIDA, 2000, MALAQUIAS ET AL. 2007, SCHOENELL ET AL, 2013; NETO ET. AL, 2015; SANTOS, 2007): a) Depreciação Acelerada; b) Depreciação acelerada incentivada; c) Juros sobre o capital próprio; d) incentivos fiscais, tendo em vista a obrigatoriedade de evidenciação dessas práticas, de acordo com o CPC 32.

\subsection{Variáveis dependentes e independentes}

Segundo Morais (2003), a variável é configurada como qualquer característica mensurável ou descritível do objeto alvo de investigação e pode ser classificada como: nominal (objetiva identificar); ordinal (objetiva identificar e ordenar); discreta (corresponde a uma contagem) ou contínua (corresponde a uma medida). Já em relação à posição, uma variável pode ser classificada como: dependente, independente ou interveniente.

Além das variáveis representadas por práticas tributárias, citadas no

referencial teórico da presente pesquisa, foram selecionadas algumas variáveis de controle com base em estudos anteriores (LANIS; RICHARDSON, 2014, 2012; 
BEASLEY, 1996; LOEBBECKE, 1989; HUSEYNOV; KLAMM, 2012; CABELLO, 2012), que podem ser consideradas fatores que exercem possível influência sobre a variável dependente de elisão fiscal (ETR).

Para coletar os dados necessários a fim de verificar a relação entre responsabilidade social e práticas de elisão físcal nas empresas brasileiras, na presente pesquisa foram relacionadas as seguintes variáveis:

( a ) variáveis independentes:

i. adoção do JSCP;

ii. adoção da Depreciação Acelerada ou Depreciação Acelerada Incentivada iii.utilização de Incentivos Fiscais Federais do IRPJ e CSLL

iv. Certificada no Índice de Sustentabilidade Empresarial

v. Tamanho da Empresa

vi. Auditoria

vii.Idade de Oferta pública da ação

(b) variável dependente - Taxa Tributária Efetiva: que será calculada pela razão entre a soma das despesas com IRPJ e CSLL e o LAIR para o período da análise (Equação 1):

ETR CORRENTE $=$ Effective Tax Rate $=\frac{\text { despesa corrente de imposto de renda e contribuição social }}{\text { Lucro antes do imposto de renda e contribuição social }}$

A escolha da ETR ocorreu, por essa taxa detectar se há práticas tributárias nas companhias, uma vez que uma gestão tributária bem estruturada acarreta uma redução das taxas efetivas de tributos. Os estudos de Schmidt (2006), Dyreng et al. (2008), Gupta e Newberry (1997), Rego (2003), Wilson (2009), utilizaram esta medida para detectar se há práticas tributárias nas companhias.

Como citado no referencial teórico deste estudo, Hanlon e Heitzman (2010), Lanis e Richardson (2012) e Rego (2003) especificamente, citam a utilização da ETR em pesquisas tributárias como indicação do planejamento tributário e consequente ferramenta de mensuração da elisão fiscal (tax avoidance).

\subsection{Base para regressão}


Os modelos de painel fazem uma análise quantitativa das relações econômicas, utilizando-se simultaneamente de dados temporais (time-series) e seccionais (cross-section) no mesmo modelo. Com dados em painel pode-se explorar simultaneamente as variações das variáveis ao longo do tempo e entre diferentes indivíduos. Os indivíduos podem representar um conjunto de países, regiões, setores, empresas, consumidores, etc. (Wooldridge, 2003; Gujarati; 2003; Stock \& Watson, 2007; Dougherty, 2007).

A apresentação dos modelos em dados em painel difere da apresentação dos modelos com dados temporais ou seccionais, pois apresentam índice duplo: um para o período e um para o indivíduo. O período trabalhado neste estudo compreende os anos de 2009 a 2013 e os indivíduos são 72 empresas listadas na BM\&FBOVESPA segregadas em certificadas pelo ISE e não certificadas pelo ISE.

Conforme Gujarati (2003) há três tipos de modelos com dados em painel:

Modelos agregados "Pooled": nestes modelos a estimação é feita assumindo que os parâmetros a (constante) e b (declives) são comuns para todos os indivíduos, ou seja, há homogeneidade na parte constante e no declive:

$$
\text { ETR }_{i t}=\alpha+\beta_{1} \text { RS }_{i t}+\beta_{2} \text { IDP }_{i t}+\beta_{3} \text { BIG4AUDIT }_{i t}+\beta_{4} J_{S C P}+\beta_{5} \text { TAM }_{i t}+\beta_{6} \text { DAI }_{i t}+u_{i}
$$

Com $i=1,2,3,4,5,6, \ldots, 72$ (empresas ordenadas por nome, em ordem alfabética crescente)

$$
\begin{aligned}
& t=1,2, \ldots, 19 .(2009,2010,2011,2012,2013) \\
& \text { i x } t=72 \times 5=360 \text { observações }
\end{aligned}
$$

Onde:

- ETR - Effective tax Rate calculada pela razão entre a soma das despesas com IRPJ e CSLL e o LAIR para o período da análise;

- $\mathrm{RS}$ - Responsabilidade Social denotada pelo índice de responsabilidade social (SIM ou NÃO) variável binária, sendo (1) se a empresa tiver certificada pelo ISE e (0) caso a empresa faça parte do grupo de controle.

- IDP - Idade de oferta pública da ação - definido como logaritmo natural do número de anos que as ações da empresa estão negociadas na bolsa. 
- TAM - Tamanho da empresa- elaborada a partir de dois indicadores (a) logaritmo natural $^{6}$ do total dos ativos e (b) logaritmo natural de receita operacional;

- DAI - Depreciação acelerada incentivada (menção da utilização nas Notas Explicativas - SIM ou NÃO) variável binária, sendo (1) se a empresa usufruir do incentivo e (0) caso a empresa não tiver adotado a prática;

- JSCP - Juros sobre o capital próprio (menção do pagamento de JSCP nas Notas Explicativas - SIM ou NÃO) variável binária, sendo (1) se a empresa tiver efetuado pagamento e (0) caso a empresa não tiver adotado a prática;

- BIG4AUDIT- variável binária que avaliará se a empresa (1) teve o relatório anual auditado por uma das quatro maiores empresas de auditoria ou (0) se o relatório anual foi auditado por uma empresa de auditoria não participante do grupo das quatro maiores;

$\varepsilon-$ Erro da regressão

$\beta$ - Coeficientes estimados da regressão

Modelos com "efeitos fixos": nestes modelos, a estimação é feita assumindo que a heterogeneidade dos indivíduos se capta na parte constante, que é diferente de indivíduo para indivíduo, captando diferenças invariantes no tempo:

$\mathrm{ETR}_{i t}=\alpha_{i}+\beta_{1} \mathrm{RS}_{\mathrm{it}}+\beta_{2} \mathrm{IDP}_{i t}+\beta_{3}$ BIG4AUDIT $_{\text {it }}+\beta_{4} \mathrm{JSCP}_{i t}+\beta_{5}$ TAM $_{\text {it }}+\beta_{6}$ DAI $_{i t}+u_{\mathrm{i}}$

Modelos com "efeitos aleatórios". Nestes modelos, a estimação é feita introduzindo a heterogeneidade dos indivíduos no termo de erro. Os modelos com efeitos aleatórios consideram a constante não como um parâmetro fixo, mas como um parâmetro aleatório não observável. Os modelos com efeitos fixos consideram que as diferenças dos indivíduos captam-se na parte constante. Já os modelos com efeitos aleatórios consideram que estas diferenças captam-se no termo de erro. Sendo assim temos:

$$
\begin{aligned}
\mathbf{E T R}_{\mathbf{i t}}=\boldsymbol{\alpha} & +\boldsymbol{\beta}_{\mathbf{1}} \mathbf{R S}_{\mathrm{it}}+\boldsymbol{\beta}_{\mathbf{3}} \mathbf{I D P}_{\mathbf{i t}}+\boldsymbol{\beta}_{\mathbf{5}} \mathbf{T A M}_{\mathrm{it}}+\boldsymbol{\beta}_{\mathbf{6}} \mathbf{D A I}_{\mathrm{it}}+\boldsymbol{\beta}_{7} \mathbf{J S C P}_{\mathbf{i t}}+\boldsymbol{\beta}_{\mathbf{1 0}} \text { BIG4AUDIT }_{i t}+\left(\mathbf{u}_{\mathbf{i}}+\mathbf{v}_{\mathbf{i}}\right) \\
& \text { Com } \alpha_{i}=\alpha+\mathrm{v}_{\mathrm{i}} \\
& \text { Onde: }
\end{aligned}
$$

$\mathbf{i}$ indica a empresa; $\mathbf{t}$ representa o ano; e $\boldsymbol{\alpha}$ uma constante comum a todas as empresas

\footnotetext{
${ }^{6} \mathrm{O}$ uso do logaritmo nos itens "TAM" e "IDP" tem por finalidade reduzir a heterocedasticidade do modelo (GRAY et. al., 2001; RICHARDSON et. al., 2001; REVERTE, 2008; MURCIA; SANTOS, 2009; MURCIA; SOUZA, 2009);
} 
Quadro 2: Variáveis utilizadas no estudo e sinal esperado.

\begin{tabular}{|c|c|c|c|}
\hline Variável & Valor assumido & $\begin{array}{c}\text { Sinal } \\
\text { esperado }\end{array}$ & Embasamento Teórico \\
\hline $\begin{array}{l}\text { ETR: } \\
\text { Efetive Tax Rate }\end{array}$ & $\frac{\text { despesa de IR e CSLL }}{L A I R}$ & $\begin{array}{l}\text { Não se } \\
\text { aplica }\end{array}$ & $\begin{array}{l}\text { Hanlon e Heitzman (2010), Cabello } \\
\text { (2012), Shackelford e Shevlin } \\
\text { (2001), Rego (2003), Tang (2006), } \\
\text { Lanis e Richardson (2014), Lanis e } \\
\text { Richardson (2012), Tang (2006) }\end{array}$ \\
\hline $\begin{array}{c}\text { RS: } \\
\text { Responsabilidade } \\
\text { Social }\end{array}$ & $\begin{array}{c}\text { Assume } 1 \text { se a empresa tiver } \\
\text { certificada pelo ISE e } 0 \text { caso a empresa } \\
\text { faça parte do grupo de controle }\end{array}$ & + & $\begin{array}{l}\text { Diccico (2002), Lanis e Richardson } \\
\text { (2011), Lanis e Richardson (2012), } \\
\text { Hoi et al. (2013), Huseynov e } \\
\text { Klamm (2012), Teixeira e Nossa } \\
\text { (2010), Bassen, Meyer e Schlange } \\
\text { (2006), Orlitzky e Benjamin (2001). }\end{array}$ \\
\hline $\begin{array}{c}\text { TAM: } \\
\text { Tamanho da empresa }\end{array}$ & $\begin{array}{l}\text { Logaritmo natural do ativo total e } \\
\text { receita operacional de cada empresa } \\
\text { para cada ano. }\end{array}$ & - & $\begin{array}{c}\text { Rego (2003), Watts e Zimmerman } \\
\text { (1986), Riahi-Belkaoui e Karpik } \\
\text { (1988), Richardson e Lanis (2007) }\end{array}$ \\
\hline $\begin{array}{l}\text { IDP: Idade de oferta } \\
\text { pública da ação }\end{array}$ & $\begin{array}{l}\text { Logaritmo natural do número de anos } \\
\text { que as ações da empresa estão } \\
\text { negociadas na bolsa. }\end{array}$ & + & $\begin{array}{c}\text { Beasley (1996), Lanis e Richardson } \\
\text { (2011) }\end{array}$ \\
\hline $\begin{array}{c}\text { DAI: Depreciação } \\
\text { Acelerada e } \\
\text { Depreciação } \\
\text { Acelerada Incentivada }\end{array}$ & $\begin{array}{c}\text { Assume } 1 \text { se a empresa usufruir do } \\
\text { incentivo e } 0 \text { caso a empresa não tiver } \\
\text { adotado a prática }\end{array}$ & - & $\begin{array}{c}\text { Aarbu e Mackie-Mason (2003), } \\
\text { Waegenaere e Wielhouwer (2011), } \\
\text { Cabello (2012), Pohlmann e } \\
\text { Iudícibus (2006), Chaves (2010), } \\
\text { Freitas et al (2007). }\end{array}$ \\
\hline $\begin{array}{l}\text { BIG4AUDIT: } \\
\text { Serviço de Auditoria }\end{array}$ & $\begin{array}{c}\text { Assume } 1 \text { se teve o relatório anual } \\
\text { auditado por uma das quatro maiores } \\
\text { empresas de auditoria e } 0 \text { se o relatório } \\
\text { anual foi auditado por uma empresa de } \\
\text { auditoria não participante do grupo das } \\
\text { quatro maiores }\end{array}$ & + & $\begin{array}{l}\text { Archambault e Archambault, } \\
\text { (2003), Murcia e Santos (2009), } \\
\text { Murcia e Souza (2009), Lanis e } \\
\text { Richardson (2013), Matsumura e } \\
\text { Tucker (1992), Rezaee (2005), } \\
\text { Wallace e Nasser (1996) }\end{array}$ \\
\hline $\begin{array}{l}\text { IF: } \\
\text { Incentivos Fiscais }\end{array}$ & $\begin{array}{c}\text { Assume } 1 \text { se a empresa adotar a prática } \\
\text { e } 0 \text { caso a empresa não tiver usufruir } \\
\text { de nenhum incentivo }\end{array}$ & - & $\begin{array}{c}\text { Janssen (2005), Formigoni (2008), } \\
\text { Cabello (2012), Chaves (2010), } \\
\text { Paranaiba e Marques (2013), } \\
\text { Almeida (2000), }\end{array}$ \\
\hline $\begin{array}{c}\text { JSCP: } \\
\text { Juros sobre o capital } \\
\text { próprio }\end{array}$ & $\begin{array}{c}\text { Assume } 1 \text { se a empresa tiver efetuado } \\
\text { pagamento e } 0 \text { caso a empresa não } \\
\text { tiver adotado a prática } \\
\text {. }\end{array}$ & - & $\begin{array}{c}\text { Malaquias et al. (2007), Cabello } \\
\text { (2012), Pohlmann e Iudícibus } \\
\text { (2006), Chaves (2010), Schoenell et } \\
\text { al (2013), Neto et. al. (2015), Santos } \\
\text { (2007). }\end{array}$ \\
\hline \&: Termo de erro & Não se aplica & $\begin{array}{l}\text { Não se } \\
\text { aplica }\end{array}$ & Não se aplica \\
\hline
\end{tabular}

Fonte: Elaboração própria. 


\section{TRATAMENTO E ANÁLISE DOS RESULTADOS}

\subsection{Análise Descritiva}

Este tópico apresenta a análise descritiva dos dados segregados em dois grupos: Certificadas pelo ISE (C) e Não Certificadas pelo ISE (NC).

Foram analisadas 44 empresas nos anos de 2009 e 2012, 48 empresas nos ano de 2010, 2011 e 2013 totalizando 72 empresas analisadas dentro do período de 2009 a 2013. A seguir é apresentada a distribuição por setor de atividade em cada ano. Segue Tabela 2 com número de empresas por setor.

Tabela 2 - Empresas pesquisadas - 2009 a 2013 (classificação de setor segundo economática)

\begin{tabular}{|c|c|c|c|c|c|c|}
\hline SETOR DE ATIVIDADE & \begin{tabular}{|l|l}
$N^{0}$ de \\
empresas
\end{tabular} & 2009 & 2010 & 2011 & 2012 & 2013 \\
\hline Abatedouros & 2 & 2 & 2 & 0 & 0 & 2 \\
\hline Administração de empresas e empreendimentos & 2 & 0 & 2 & 2 & 2 & 0 \\
\hline Agua, esgoto e outros sistemas & 4 & 2 & 4 & 4 & 2 & 4 \\
\hline Atividades auxiliares ao transporte rodoviário & 4 & 0 & 0 & 2 & 4 & 4 \\
\hline Comércio atacadista de bens não duráveis variados & 2 & 2 & 2 & 2 & 2 & 2 \\
\hline Construção de edifícios residenciais & 2 & 2 & 2 & 2 & 0 & 2 \\
\hline Bens Industriais, máquinas e equipamentos & 2 & 0 & 0 & 0 & 0 & 2 \\
\hline Geração, transmissão e distribuição de energia elétrica & 22 & 20 & 20 & 20 & 20 & 16 \\
\hline Indústria de autopeças, equipamentos aeroespacias & 2 & 0 & 2 & 2 & 0 & 2 \\
\hline Indústria de máquinas industriais & 2 & 2 & 2 & 0 & 0 & 0 \\
\hline $\begin{array}{l}\text { Indústria de móveis, produtos de madeira compensada e } \\
\text { afins }\end{array}$ & 2 & 0 & 2 & 2 & 2 & 2 \\
\hline Indústria de papel, celulose e papelão & 6 & 4 & 4 & 2 & 4 & 4 \\
\hline Indústria química & 2 & 0 & 0 & 2 & 2 & 0 \\
\hline Mineração de metais & 2 & 0 & 2 & 2 & 0 & 0 \\
\hline Serv.Méd.Hospit..Análises e Diagnósticos & 4 & 2 & 0 & 0 & 0 & 2 \\
\hline Telecomunicações & 6 & 2 & 0 & 2 & 2 & 6 \\
\hline Transformação de aço em produtos de aço, fundição & 6 & 6 & 4 & 4 & 4 & 0 \\
\hline TOTAL & 72 & 44 & 48 & 48 & 44 & 48 \\
\hline
\end{tabular}

Fonte: Elaboração própria. 
Observando a Tabela 2 constata-se que o setor com maior representatividade em número de empresas na amostra, em todos os anos, é o setor de energia elétrica, seguido pelo de transformação de aço em produtos de aço, fundição e indústria de papel e celulose. A maior parte dos setores é representado por duas empresas considerando que tem-se uma empresa certificada pelo ISE e uma empresa correspondente que faz parte do mesmo setor porém não é certificada pelo ISE.

A distribuição por práticas tributárias escolhidas dentre as empresas analisadas é evidenciada na Tabela 3, conforme segue:

Tabela 3 - Distribuição por prática ou grupo de práticas tributárias escolhidas - 2009 a 2013

\begin{tabular}{|c|c|c|c|c|c|c|c|c|c|c|}
\hline \multirow[b]{2}{*}{$\begin{array}{l}\text { Práticas } \\
\text { Tributárias }\end{array}$} & \multicolumn{2}{|c|}{2009} & \multicolumn{2}{|c|}{2010} & \multicolumn{2}{|c|}{2011} & \multicolumn{2}{|c|}{2012} & \multicolumn{2}{|c|}{2013} \\
\hline & $\begin{array}{l}\mathrm{N}^{\circ} \text { de } \\
\text { emp. }\end{array}$ & $\begin{array}{l}\% \text { de } \\
\text { emp. }\end{array}$ & $\begin{array}{l}N^{\circ} \text { de } \\
\text { emp. }\end{array}$ & $\begin{array}{l}\% \text { de } \\
\text { emp. }\end{array}$ & $\begin{array}{l}\mathrm{N}^{\circ} \text { de } \\
\text { emp. }\end{array}$ & $\begin{array}{l}\% \text { de } \\
\text { emp. }\end{array}$ & $\begin{array}{l}N^{\circ} \text { de } \\
\text { emp. }\end{array}$ & $\begin{array}{l}\% \text { de } \\
\text { emp. }\end{array}$ & $\begin{array}{l}N^{\circ} \text { de } \\
\text { emp. }\end{array}$ & $\begin{array}{l}\% \text { de } \\
\text { emp. }\end{array}$ \\
\hline $\begin{array}{l}\text { nenhuma } \\
\text { prática }\end{array}$ & 9 & $20 \%$ & 7 & $15 \%$ & 5 & $10 \%$ & 4 & $9 \%$ & 8 & $17 \%$ \\
\hline $\begin{array}{l}\text { somente } \\
\text { JSCP }\end{array}$ & 13 & $30 \%$ & 12 & $25 \%$ & 11 & $23 \%$ & 11 & $25 \%$ & 16 & $33 \%$ \\
\hline $\begin{array}{c}\text { somente } \\
\text { DAI ou DA }\end{array}$ & 0 & $0 \%$ & 0 & $0 \%$ & 0 & $0 \%$ & 0 & $0 \%$ & 0 & $0 \%$ \\
\hline somente IF & 4 & $9 \%$ & 7 & $15 \%$ & 5 & $10 \%$ & 4 & $9 \%$ & 6 & $13 \%$ \\
\hline $\begin{array}{c}\text { somente } \\
\text { JSCP e DAI } \\
\text { ou DA }\end{array}$ & 1 & $2 \%$ & 1 & $2 \%$ & 0 & $0 \%$ & 0 & $0 \%$ & 0 & $0 \%$ \\
\hline $\begin{array}{l}\text { somente } \\
\text { JSCP e IF }\end{array}$ & 13 & $30 \%$ & 16 & $33 \%$ & 22 & $46 \%$ & 20 & $45 \%$ & 13 & $27 \%$ \\
\hline $\begin{array}{c}\text { somente } \\
\text { DAI ou DA } \\
\text { e IF }\end{array}$ & 0 & $0 \%$ & 0 & $0 \%$ & 2 & $4 \%$ & 1 & $2 \%$ & 1 & $2 \%$ \\
\hline $\begin{array}{l}\text { JSCP, DAI } \\
\text { ou DA e IF }\end{array}$ & 4 & $9 \%$ & 5 & $10 \%$ & 3 & $6 \%$ & 4 & $9 \%$ & 4 & $8 \%$ \\
\hline Total & 44 & $100 \%$ & 48 & $100 \%$ & 48 & $100 \%$ & 44 & $100 \%$ & 48 & $100 \%$ \\
\hline
\end{tabular}

Fonte: Elaboração própria.

Na Tabela 3 observa-se que houve uma queda ao longo de 2009 a 2012 das empresas pesquisadas que não adotavam nenhuma das práticas tributárias elencadas ${ }^{7}$

\footnotetext{
${ }^{7}$ Depreciação Acelerada; Depreciação acelerada incentivada; Juros sobre o capital próprio; incentivos fiscais
} 
nesta pesquisa. Em 2009, 20\% das empresas não apresentaram nenhuma prática enquanto que em 2012 apenas 9\% das empresas não apresentaram a adoção de práticas tributárias. Em 2013 o número de empresas que não adotou nenhuma das práticas aumentou elevando o percentual para $17 \%$. Por outro lado, as empresas que escolheram adotar todas as práticas tributárias destacadas na análise se mantiveram constante ao longo dos anos variando entre $10 \%$ e $6 \%$. Esta ocorrência pode ser justificada pelo fato de algumas empresas apresentarem Patrimônio Líquido negativo e não terem a possibilidade de apurar JSCP, ou não escolheram fazer uso de qualquer tipo de depreciação acelerada, ou utilização de incentivos fiscais. Sendo assim, o percentual em torno de $10 \%$ a 6\%, que representa as empresas com adoção de todas as práticas tributárias elencadas no estudo, pode não ser relevante para efeito da análise, devido à existência de impossibilidades de adoção de práticas tributárias, porém, pode ser relevante observando se aquelas que empregam todas as práticas tributárias possuem ETR inferior àquelas que empregam duas, uma ou nenhuma prática tributária. Nota-se que em todos os anos, a única prática tributária que não foi adotada de forma isolada, ou seja, nenhuma empresa adotou apenas esta prática, foi a depreciação acelerada ou depreciação acelerada incentivada. Fica evidente na tabela 3 uma predominância de empresas, para todos os anos, que optaram em adotar alguma prática tributária ou conjunto de práticas tributárias elencadas no estudo. $\mathrm{O}$ percentual de empresas que adotaram alguma prática ou conjunto de práticas varia entre $80 \%$ e $91 \%$ no período de 2009 a 2013. Este resultado demonstra que para todos os anos analisados, de forma geral, tanto as empresas que são certificadas pelo ISE como as que não são certificadas, estão optando por escolhas de práticas tributárias de elisão fiscal.

As tabelas 4 e 5 a seguir corroboram os dados da tabela anterior no que tange a escolha das práticas tributárias segregando empresas certificadas e não certificadas pelo ISE. A tabela foi elaborada abordando apenas as práticas tributárias elencadas neste estudo limitando-se a depreciação acelerada, depreciação acelerada incentivada, juros sobre o capital próprio e incentivos fiscais, o que permitiu uma análise e comparação da adoção de alguma prática ou grupo de práticas tributárias. 
Tabela 4 - Distribuição por prática ou grupo de práticas tributárias adotadas por empresas certificadas pelo ISE - 2009 a 2013

\begin{tabular}{|c|c|c|c|c|c|c|c|c|c|c|}
\hline \multirow{2}{*}{$\begin{array}{l}\text { Práticas } \\
\text { Tributárias }\end{array}$} & \multicolumn{2}{|c|}{2009} & \multicolumn{2}{|c|}{2010} & \multicolumn{2}{|c|}{2011} & \multicolumn{2}{|c|}{2012} & \multicolumn{2}{|c|}{2013} \\
\hline & $\begin{array}{l}N^{\circ} \text { de } \\
\text { emp. }\end{array}$ & $\begin{array}{l}\% \text { de } \\
\text { emp. }\end{array}$ & $\begin{array}{l}N^{\circ} \text { de } \\
\text { emp. }\end{array}$ & $\begin{array}{l}\% \text { de } \\
\text { emp. }\end{array}$ & $\begin{array}{l}N^{\circ} \text { de } \\
\text { emp. }\end{array}$ & $\begin{array}{l}\% \text { de } \\
\text { emp. }\end{array}$ & $\begin{array}{l}N^{\circ} \text { de } \\
\text { emp. }\end{array}$ & $\begin{array}{l}\% \text { de } \\
\text { emp. }\end{array}$ & $\begin{array}{l}N^{\circ} \text { de } \\
\text { emp. }\end{array}$ & $\begin{array}{l}\% \text { de } \\
\text { emp. }\end{array}$ \\
\hline $\begin{array}{l}\text { Nenhuma } \\
\text { prática }\end{array}$ & 3 & $14 \%$ & 1 & $4 \%$ & 1 & $4 \%$ & 1 & $5 \%$ & 2 & $8 \%$ \\
\hline Somente JSCP & 7 & $32 \%$ & 7 & $29 \%$ & 5 & $21 \%$ & 5 & $23 \%$ & 8 & $33 \%$ \\
\hline $\begin{array}{c}\text { Somente DAI ou } \\
\text { DA }\end{array}$ & 0 & $0 \%$ & 0 & $0 \%$ & 0 & $0 \%$ & 0 & $0 \%$ & 0 & $0 \%$ \\
\hline Somente IF & 1 & $5 \%$ & 3 & $13 \%$ & 2 & $8 \%$ & 2 & $9 \%$ & 3 & $13 \%$ \\
\hline $\begin{array}{l}\text { Somente JSCP e } \\
\text { DAI ou DA }\end{array}$ & 0 & $0 \%$ & 0 & $0 \%$ & 0 & $0 \%$ & 0 & $0 \%$ & 0 & $0 \%$ \\
\hline $\begin{array}{c}\text { Somente JSCP e } \\
\text { IF }\end{array}$ & 9 & $41 \%$ & 10 & $42 \%$ & 14 & $58 \%$ & 12 & $55 \%$ & 8 & $33 \%$ \\
\hline $\begin{array}{c}\text { Somente DAI ou } \\
\text { DA e IF }\end{array}$ & 0 & $0 \%$ & 0 & $0 \%$ & 1 & $4 \%$ & 0 & $0 \%$ & 0 & $0 \%$ \\
\hline $\begin{array}{l}\text { JSCP, DAI ou } \\
\text { DA e IF }\end{array}$ & 2 & $9 \%$ & 3 & $13 \%$ & 1 & $4 \%$ & 2 & $9 \%$ & 3 & $13 \%$ \\
\hline Total & 22 & $100 \%$ & 24 & $100 \%$ & 24 & $100 \%$ & 22 & $100 \%$ & 24 & $100 \%$ \\
\hline
\end{tabular}

Fonte: Elaboração própria.

O que é possível perceber a partir da tabela 4, é que para todos os anos a maioria das empresas certificadas optou por escolher alguma prática ou conjunto de práticas verificando um percentual entre 96\% e 86\% dentro de 2009 e 2013. Considerando a adoção de apenas uma prática, as empresas do ISE em todos os anos apresentaram uma maior opção pelo pagamento de juros sobre o capital próprio sendo que a depreciação acelerada ou depreciação acelerada incentivada não foi adotada como única prática em nenhum dos anos. 
Tabela 5 - Distribuição por prática ou grupo de práticas tributárias adotadas por empresas não certificadas pelo ISE - 2009 a 2013

\begin{tabular}{|c|c|c|c|c|c|c|c|c|c|c|}
\hline \multirow{2}{*}{$\begin{array}{l}\text { Práticas } \\
\text { Tributárias }\end{array}$} & \multicolumn{2}{|c|}{2009} & \multicolumn{2}{|c|}{2010} & \multicolumn{2}{|c|}{2011} & \multicolumn{2}{|c|}{2012} & \multicolumn{2}{|c|}{2013} \\
\hline & $\begin{array}{l}\mathrm{N}^{\circ} \text { de } \\
\text { emp. }\end{array}$ & $\begin{array}{l}\% \text { de } \\
\text { emp. }\end{array}$ & $\begin{array}{l}N^{\circ} \text { de } \\
\text { emp. }\end{array}$ & $\begin{array}{l}\% \text { de } \\
\text { emp. }\end{array}$ & $\begin{array}{l}\mathrm{N}^{\circ} \text { de } \\
\text { emp. }\end{array}$ & $\begin{array}{l}\% \text { de } \\
\text { emp. }\end{array}$ & $\begin{array}{l}\mathrm{N}^{\circ} \text { de } \\
\text { emp. }\end{array}$ & $\begin{array}{l}\% \text { de } \\
\text { emp. }\end{array}$ & $\begin{array}{l}\mathrm{N}^{\circ} \text { de } \\
\text { emp. }\end{array}$ & $\begin{array}{l}\% \text { de } \\
\text { emp. }\end{array}$ \\
\hline Nenhuma prática & 6 & $27 \%$ & 6 & $25 \%$ & 4 & $17 \%$ & 3 & $14 \%$ & 6 & $25 \%$ \\
\hline Somente JSCP & 6 & $27 \%$ & 5 & $21 \%$ & 6 & $25 \%$ & 6 & $27 \%$ & 8 & $33 \%$ \\
\hline $\begin{array}{c}\text { Somente DAI ou } \\
\text { DA }\end{array}$ & 0 & $0 \%$ & 0 & $0 \%$ & 0 & $0 \%$ & 0 & $0 \%$ & 0 & $0 \%$ \\
\hline Somente IF & 3 & $14 \%$ & 4 & $17 \%$ & 3 & $13 \%$ & 2 & $9 \%$ & 3 & $13 \%$ \\
\hline $\begin{array}{c}\text { Somente JSCP e } \\
\text { DAI ou DA }\end{array}$ & 1 & $5 \%$ & 1 & $4 \%$ & 0 & $0 \%$ & 0 & $0 \%$ & 0 & $0 \%$ \\
\hline $\begin{array}{c}\text { Somente JSCP e } \\
\text { IF }\end{array}$ & 4 & $18 \%$ & 6 & $25 \%$ & 8 & $33 \%$ & 8 & $36 \%$ & 5 & $21 \%$ \\
\hline $\begin{array}{c}\text { Somente DAI ou } \\
\text { DA e IF }\end{array}$ & 0 & $0 \%$ & 0 & $0 \%$ & 1 & $4 \%$ & 1 & $5 \%$ & 1 & $4 \%$ \\
\hline $\begin{array}{c}\text { JSCP, DAI ou } \\
\text { DA e IF } \\
\end{array}$ & 2 & $9 \%$ & 2 & $8 \%$ & 2 & $8 \%$ & 2 & $9 \%$ & 1 & $4 \%$ \\
\hline Total & 22 & 100 & 24 & $100 \%$ & 24 & $100 \%$ & 22 & $100 \%$ & 24 & $100 \%$ \\
\hline
\end{tabular}

Fonte: Elaboração própria

Partindo do exposto pela tabela 5, as empresas analisadas pelo estudo classificadas como não certificadas pelo ISE, apresentaram uma menor quantidade de empresas que escolheram alguma prática ou conjunto de práticas tributárias para todos os anos analisados. O percentual de empresas que não optaram por nenhuma prática variou entre $14 \%$ e $27 \%$ e as empresas que fizeram a escolha por alguma prática ou conjunto de práticas variou entre $86 \%$ e $73 \%$. Assim como verificado a partir das tabelas 4 e 5 as empresas classificadas como certificadas e as empresas do grupo de controle também apresentaram maior pagamento de juros sobre o capital próprio como única prática tributária adotada.

Ao comparar as tabelas 4 e 5, e tomando como base a opção por não adotar nenhuma prática tributária, é possível perceber que em todos os anos as empresas classificadas como certificadas apresentaram menor percentual de empresas que não escolheram nenhuma prática. Em 2010 tem-se a maior diferença, destacando 4\% das empresas certificadas não optaram por nenhuma prática enquanto que $25 \%$ das empresas não certificadas optaram por não escolher nenhuma prática tributária. Sendo 
assim, comparando as empresas dos dois grupos, é possível afirmar que em maior quantidade, as empresas do ISE sempre optaram por alguma prática ou por grupo de práticas tributárias. Analisando a adoção por todas as práticas tributárias elencadas neste estudo, nota-se um percentual equiparado entre os dois grupos de empresas. Em 2009 por exemplo, o percentual de empresas certificadas que optaram por todas as práticas foi o mesmo de empresas não certificadas apresentando $9 \%$ das empresas de cada grupo. É possível sintetizar que quanto à adoção de todas as práticas simultaneamente, tanto as empresas do ISE como as que não compõem o grupo, estão equilibradas, porém quando se trata em adotar pelo menos alguma prática, as empresas do ISE apresentam um percentual elevado, indicando que a maioria sempre escolhe alguma prática ou grupo de práticas.

Tabela 6 - Estatísticas descritivas da Efetive Tax Rate (ETR)

\begin{tabular}{l|c|c|c|c|c|c|c|c|c|c}
\hline & \multicolumn{2}{|c|}{2009} & \multicolumn{2}{c|}{2010} & \multicolumn{2}{c|}{$\mathbf{2 0 1 1}$} & \multicolumn{2}{|c|}{2012} & \multicolumn{2}{c}{$\mathbf{2 0 1 3}$} \\
\hline & $\mathbf{C}$ & $\mathbf{N C}$ & $\mathbf{C}$ & $\mathbf{N C}$ & $\mathbf{C}$ & $\mathbf{N C}$ & $\mathbf{C}$ & $\mathbf{N C}$ & $\mathbf{C}$ & $\mathbf{N C}$ \\
\hline Média & 0,3043 & 0,379 & 0,2578 & 0,4449 & 0,3255 & 0,3160 & 0,2858 & 0,2917 & 0,2718 & 0,4351 \\
\hline Mediana & 0,2646 & 0,289 & 0,2585 & 0,1905 & 0,2772 & 0,1996 & 0,2962 & 0,2426 & 0,2723 & 0,1833 \\
\hline $\begin{array}{l}\text { Desvio } \\
\text { Padrão }\end{array}$ & 0,3277 & 0,306 & 0,0874 & 0,9774 & 0,2358 & 0,3459 & 0,1335 & 0,2771 & 0,0946 & 0,9153 \\
\hline Assimetria & 3,5680 & 2,637 & 0,4590 & 4,7270 & 3,3390 & 2,3520 & 0,1770 & 3,5410 & 0,2870 & 4,1710 \\
\hline Curtose & 14,917 & 7,869 & 0,4590 & 22,791 & 13,516 & 5,0330 & 1,2920 & 14,864 & 0,3540 & 18,281 \\
\hline
\end{tabular}

Fonte: Elaboração própria

Tomando como base os dados apresentados na tabela 7, as médias e as medianas das ETRs encontradas para as empresas certificadas possuem valores proporcionais ao longo do período analisado. Verifica-se uma curva assimétrica positiva para os anos de 2009 e 2011 onde a média das ETRs estão superiores à mediana. Em 2010, 2012 e 2013 têm-se a maior parte dos dados à esquerda da mediana o que demonstra uma curva assimétrica negativa para as ETRs desses anos. Esses indicadores permitem que se tenha uma visão do modo como se distribuem os dados de uma amostra, constatando-se que a média da ETR das empresas certificadas é de, aproximadamente, 0,3196, e a mediana é 0,2546 pode-se reforçar a afirmação de que a maior parte dos dados referentes à ETR das empresas certificadas estão dispersos à esquerda da medida central. 
Os desvios padrões das ETRs nos anos de 2009 e 2011 foram mais altos, o que indica que nesses anos a dispersão dos dados foi maior. Por meio do desvio padrão é possível identificar até que ponto os resultados se concentram ou não ao redor da tendência central do conjunto da ETR de empresas certificadas. A curtose mais elevada foi verificada para os anos de 2009 e 2011, indicando que nesses anos há o maior grau de achatamento e afunilamento da curva que descreve a distribuição das amostras, levando em consideração a curva normal.

Ao analisar as médias e as medianas das ETRs das empresas não certificadas, nota-se que os dados diferem-se bastante de um ano para o outro. Para todo período analisado, verifica-se a mediana superior à média e que a amostra se afasta do eixo do centro na direção dos maiores valores o que indica que os dados formam uma curva assimétrica positiva. A média da ETR das empresas não certificadas é de, aproximadamente, 0,2506 e a mediana é de 0,3286 confirmando que para todo período analisado os dados estão à direita da mediana principalmente nos anos de 2010 e 2013, nos quais a distribuição começa a afastar-se da curva normal.

Nos mesmos dois anos, nota-se que os desvios padrões das ETRs foram mais altos, o que indica que em 2010 e 2013 a dispersão dos dados foi maior. Como consequência, a curtose é mais elevada para os anos de 2010 e 2013, indicando nestes anos o maior grau de achatamento e afunilamento da curva que descreve a distribuição das amostras, levando em consideração a curva normal.

Analisando os dados apresentados pela estatística descritiva, é possível afirmar que os dados referentes à ETR apresentaram diferença ao longo dos anos para ambos os grupos o que é confirmado a partir dos valores de desvio padrão. Embora a média de todos os anos para a ETR seja maior em empresas certificadas pelo ISE (média 0,3196), o maior valor apresentado para a mediana a qual aponta a medida central é verificada para o grupo de empresas não certificadas (mediana 0,3286), o que indica que as empresas do grupo de controle apresentam maiores valores para a ETR.

Como citado no referencial teórico deste estudo e seguindo análises encontradas em pesquisas anteriores, parte-se do pressuposto de que as empresas classificadas como socialmente responsáveis deveriam apresentar valores mais elevados para ETRs quando comparadas às demais empresas.

Ao comparar por ano as médias e medianas dos grupos de empresas classificadas como certificadas ou não certificadas pelo ISE, observa-se que nos anos de 2009, 2010 e 2013 há um resultado contrário ao esperado segundo o referencial teórico. 
As médias das ETRs de empresas não certificadas foram maiores do que as médias das empresas certificadas. A comparação dos valores para esses anos indica maior adoção de elisão fiscal por parte das empresas socialmente responsáveis. Nos anos de 2011 e 2012 as médias das empresas certificadas foram maiores indicando, para esses anos, possível maior adoção de elisão fiscal pelo grupo de controle.

Além dos valores de média e mediana, como medidas de tendência central ou localização, analisa-se, também, os quartis, conforme apresentado pela tabela 7 a seguir:

Tabela 7 - Quartis e desvio padrões das medidas de mensuração da elisão fiscal para as empresas certificadas e não certificadas

\begin{tabular}{|c|c|c|c|c|c|c|c|c|c|}
\hline \multirow[b]{3}{*}{ Indicador } & \multirow[b]{3}{*}{ Ano } & \multicolumn{4}{|c|}{ Certificadas } & \multicolumn{4}{|c|}{ Não Certificadas } \\
\hline & & $1^{0}$ & $\mathbf{2}^{\mathbf{0}}$ & $3^{\mathbf{0}}$ & $\begin{array}{l}\text { Desvio } \\
\text { Padrão }\end{array}$ & $\mathbf{1}^{\mathbf{0}}$ & $\mathbf{2}^{\mathbf{0}}$ & $\mathbf{3}^{\mathbf{0}}$ & Desvio \\
\hline & & Quartil & Quartil & Quartil & Padrão & Quartil & Quartil & Quartil & Padrão \\
\hline & 2009 & 0,2197 & 0,2898 & 0,3549 & 0,3277 & 0,1853 & 0,2646 & 0,2967 & 0,3062 \\
\hline \multirow{4}{*}{ ETR } & 2010 & 0,1604 & 0,1905 & 0,2920 & 0,0874 & 0,1759 & 0,2585 & 0,3303 & 0,9774 \\
\hline & 2011 & 0,1313 & 0,1996 & 0,3013 & 0,2358 & 0,2121 & 0,2772 & 0,3297 & 0,3459 \\
\hline & 2012 & 0,1454 & 0,2426 & 0,3302 & 0,1335 & 0,237 & 0,2962 & 0,3535 & 0,2771 \\
\hline & 2013 & 0,1208 & 0,1833 & 0,3731 & 0,0946 & 0,2234 & 0,2723 & 0,3322 & 0,9153 \\
\hline
\end{tabular}

Fonte: Elaboração própria

Ao analisar a tabela 7, verifica-se que todos os quartis referentes à ETR de empresas não certificadas são maiores nos anos de 2010, 2011 e 2012. Para o ano de 2013 tem-se os dois primeiros quartis seguindo a mesma linha, porém o terceiro quartil apresenta ETR das empresas classificadas como certificadas superior. Para o ano de 2009 tem-se todos os quartis de empresas certificadas apresentados com ETR superior comparando ao grupo de empresas não certificadas. Sendo assim, com base no período analisado, é possível afirmar que a maioria dos anos apresentam ETR maior para empresas não certificadas pelo ISE.

Quanto aos resultados obtidos a partir da análise de quartis, contrariando a expectativa inicial, com exceção do ano de 2009 os maiores valores para a ETR foram verificadas para o grupo de controle.

Considerando que um maior nível de ETR indica menores práticas de elisão fiscal, observa-se que as empresas que compõem o grupo de controle ou as empresas não certificadas pelo ISE apresentam menores índices de elisão fiscal. 
Com base na análise destes dados apresentados é possível afirmar que as empresas socialmente responsáveis, denotadas pelo ISE, possuem uma maior tendência às práticas de elisão fiscal.

\subsection{Análise da regressão com dados em painel: Elisão Fiscal e Responsabilidade} Social

Essa seção apresenta os resultados da análise da regressão com dados em painel, buscando respostas ao problema de pesquisa, de forma a corroborar ou não a hipótese central de pesquisa se há relação das empresas brasileiras que apresentam práticas socialmente responsáveis face à questão da elisão tributária.

Inicialmente é relevante destacar que os dados acerca dos Incentivos Fiscais que foram objeto constante no referencial deste estudo e serviram para contribuir na análise descritiva efetuada, foram retirados para estimar o modelo de regressão. Outro fator relevante é que a variável tamanho da empresa (TAM) considerada ao trabalhar o modelo, foi o logaritmo natural da receita operacional. Estas alterações foram necessárias visto que a partir de uma pré-análise os respectivos ajustes foram os melhores considerados a fim de se obter um modelo mais robusto.

Ao dispor os dados têm-se as variáveis na coluna, com uma variável identificando o indivíduo e o tempo. Analisando os dados em painel verificou-se que a base de dados apresenta-se incompleta, com muitos valores ausentes. Dessa forma, observa-se o tratamento de um painel desbalanceado.

Caso existam possíveis variáveis em comum no estudo, as mesmas podem causar vieses na estimação do modelo. A fim de identificar essas variáveis foi realizada inicialmente a matriz de correlação entre as variáveis do estudo a qual está apresentada a seguir.

Quadro 3 - Matriz de correlação das variáveis do estudo

\begin{tabular}{|c|c|c|c|c|c|c|c|}
\hline Variáveis & JSCP & IDP & BIG4AUDIT & DAI & TAM2 & ETR & $\mathbf{R S}$ \\
\hline JSCP & 1.00 & & & & & & \\
\hline IDP & 0.0599 & 1.00 & & & & & \\
\hline BIG4AUDIT & 0.245 & -0.0137 & 1.00 & & & & \\
\hline DAI & 0.3355 & 0.1626 & 0.0748 & 1.00 & & & \\
\hline TAM2 & 0.3355 & 0.1626 & 0.2014 & 0.1627 & 1.00 & & \\
\hline ETR & -0.124 & -0.0837 & -0.0894 & 0.025 & 0.0005 & 1.00 & \\
\hline $\mathbf{R S}$ & 0.2315 & 0.1035 & 0.2911 & 0.0294 & 0.5091 & -0.0841 & 1.00 \\
\hline
\end{tabular}


Esta matriz visa apresentar informações que permitam a verificação da correlação entre todas as variáveis do modelo além de indicar a presença de multicolinearidade, ou seja, quando há correlação alta entre as variáveis explicativas. Ao analisar a matriz verifica-se que a maior correlação entre as variáveis explicativas é encontrada ente TAM2 e RS, (0,5091), o que não pode ser considerada como alta correlação ao ponto de enviesar o modelo do estudo.

Ao considerar a possibilidade de estimação do modelo em efeitos fixos e aleatórios inicialmente foi realizada uma estimação do modelo com efeitos aleatórios e realizado o teste de Hausman para identificar se essa abordagem é a que encontra o melhor ajuste para o modelo. O resultado do teste é demonstrado a seguir.

Tabela 8 - Teste de Hausman para estimação de modelo em painel com efeitos aleatórios em crosssecion

\begin{tabular}{lccc} 
Resultado do Teste & Chi-Sq. Statistic & Chi-Sq. d.f. & Prob. \\
\hline Efeitos Aleatórios em cross-section & 0.000000 & 5 & $\mathbf{1 . 0 0 0}$ \\
\hline Fonte: Elaboração própria & & & \\
\hline
\end{tabular}

O teste de Hausman não rejeita a hipótese nula para a estimar o modelo em painel com efeitos aleatórios sendo este o modelo utilizado cuja estimação introduz a heterogeneidade dos indivíduos no termo de erro. Os modelos com efeitos aleatórios consideram a constante não como um parâmetro fixo, mas como um parâmetro aleatório não observável. Os modelos com efeitos fixos consideram que as diferenças dos indivíduos captam-se na parte constante. Já os modelos com efeitos aleatórios consideram que estas diferenças captam-se no termo de erro (Wooldridge, 2003; Gujarati; 2003; Stock \& Watson, 2007; Douguerty, 2007).

A tabela a seguir apresenta os resultados do modelo de regressão com dados em painel estimado: 
Tabela 9 - Resultados da estimação dos dados em painel com efeitos aleatórios seccionais para variável dependente elisão fiscal (ETR)

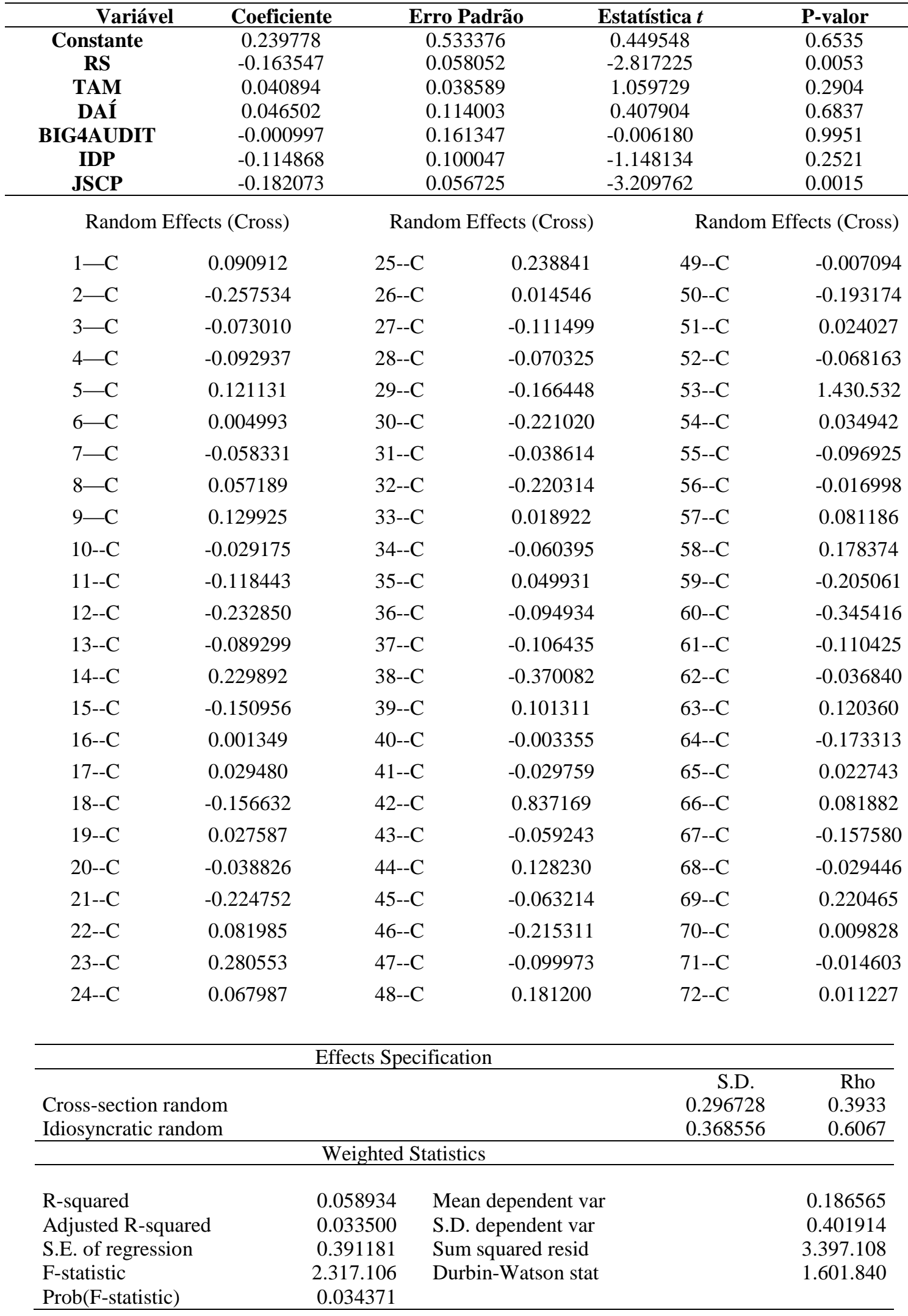


Primeiro, é possível afirmar que o modelo como um todo é significativo ao nível de $5 \%$ de significância, visto que o resultado do Teste $\mathrm{F}$ (p-valor da estatística $\mathrm{F}<0,05$ ). Observa-se também que o grau de ajuste do modelo, dado pelo r-quadrado ajustado, é de $3,35 \%$.

São significativas apenas duas variáveis: RS e JCSP visto seus p-valores inferiores a 0,05 , ou seja, estas variáveis são significativas ao nível de $5 \%$ de significância. Considerando os resultados apresentados, observa-se que o sinal da variável JSCP é negativo, corroborando a expectativa inicial. Como citado no referencial desta pesquisa, optar pelo pagamento de JSCP indica a adoção de elisão fiscal por parte das empresas. O resultado obtido por meio da regressão leva a inferir que, quanto maior o pagamento de juros sobre o capital próprio, menor a ETR e consequentemente maior o índice de elisão fiscal.

De forma contrária ao que se verifica com a variável JSCP, a RS que é representada pelo índice de responsabilidade social das empresas, se mostrou significante e não atingiu o sinal esperado possibilitando afirmar que a variável RS impacta a variável ETR de maneira inversamente proporcional, ou seja, quanto a estes resultados obtidos, contrariando a expectativa inicial, o sinal observado para a variável RS é negativo. Isto indica que as empresas classificadas como certificadas pelo ISE apresentam maior prática de elisão fiscal.

A partir dos testes realizados e dos resultados encontrados, o modelo estimado é significativo e corrobora a hipótese central da pesquisa indicando que há relação entre o nível de responsabilidade social das empresas e a adoção de práticas de elisão fiscal, isto é, empresas consideradas como socialmente responsável (certificadas pelo ISE) apresentaram maiores índice de elisão fiscal quando comparadas às demais.

A seguir será apresentado um resumo dos resultados esperados em relação aos resultados encontrados. 
Quadro 4 - Resumo dos resultados - Elisão Fiscal (ETR) e variáveis independentes

\begin{tabular}{|l|c|c|l|}
\hline \multicolumn{1}{|c|}{ Variáveis Independentes } & $\begin{array}{c}\text { Sinal } \\
\text { Esperado }\end{array}$ & \multicolumn{2}{c|}{ ETR } \\
\cline { 3 - 4 } & Sinal Observado & Sig \\
\hline Responsabilidade Social (RS) & + & - & Sim* \\
\hline Tamanho (TAM) & - & + & Não \\
\hline $\begin{array}{l}\text { Depreciação Acelerada e Depreciação Acelerada Incentivada } \\
\text { (DAI) }\end{array}$ & - & + & Não \\
\hline Serviço de Auditoria (BIG4AUDIT) & + & - & Não \\
\hline Idade de oferta pública da ação (IDP) & $\begin{array}{c}\text { não } \\
\text { previsto }\end{array}$ & - & Não \\
\hline Incentivos Fiscais (IF) & - & $\begin{array}{c}\text { retirada do } \\
\text { modelo }\end{array}$ & Não \\
\hline Juros Sobre o Capital Próprio (JSCP) & - & - & Sim* \\
\hline
\end{tabular}

Fonte: Elaboração própria

Quanto aos resultados obtidos, o sinal observado para a variável juros sobre o capital próprio corrobora com estudos anteriores como o de Santos (2001), e Sousa Filho et al. (2001), para uma amostra de empresas brasileiras. Como destacado no referencial teórico deste estudo, a opção de pagamento de JSCP é considerado uma prática tributária que impactaria proporcionalmente a variável de elisão fiscal e com os resultados obtidos verifica-se um sinal que está de acordo com o esperado. Isto demonstra que esta prática, testada nesta pesquisa, está impactando a ETR e consequentemente as práticas de elisão fiscal.

As variáveis TAM, DAI, BIG4AUDIT e IDP não foram significantes para uma amostra de empresas brasileiras dentro do período de 2009 a 2013. Embora se tenha um embasamento teórico com o uso destas variáveis em outras pesquisas, nota-se que neste estudo elas não foram significativas indicando que as práticas tributárias adotadas neste estudo (com exceção do pagamento de juros sob o capital próprio), a adoção do serviço de uma das big four, o porte da empresa e o tempo que a mesma oferta suas ações em bolsa de valores não são significantes estatisticamente.

Como apresentado no referencial teórico, a responsabilidade social corporativa envolve a tomada por decisões que reduzam o grau de custos externos e evitem conflitos distributivos reduzindo riscos. Tem-se que a adoção por práticas socialmente responsáveis acarreta em melhoria das relações com os reguladores e da produtividade dos funcionários e um menor custo de capital.

Analisando estes fatores, pode-se afirmar que as empresas certificadas como socialmente responsáveis por apresentarem aversão ao risco deveriam apresentar menores índices no que tange as práticas de elisão fiscal. Sendo assim a variável RS que 
representa índice de responsabilidade social mostrou-se significante porém não atingiu o sinal esperado evidenciando que empresas do ISE apresentam menores índices de ETR e consequentemente maiores evidências de elisão fiscal.

Este resultado não corrobora com estudos anteriores (LANIS; RICHARDSON, 2012; HOI et al. 2013) indicando que para uma amostra de 72 empresas brasileiras de capital aberto, utilizando a taxa de imposto efetiva (ETR) como medidas para mensuração de elisão fiscal e o ISE como proxy de empresas socialmente responsáveis, verifica-se maiores índices de elisão fiscal para as empresas certificadas pelo ISE.

\section{CONCLUSÕES}

O presente estudo teve como objetivo avaliar a associação de empresas com práticas de elisão fiscal e responsabilidade social. Para cumprir esse objetivo foi disposta uma amostra de empresas $(n=72)$ listadas na BM\&FBOVESPA que participam do Índice de Sustentabilidade Empresarial (ISE) mais grupo de controle composto por empresas do mesmo setor e tamanho e que não participam do ISE.

Inicialmente, foi realizada uma análise descritiva a fim de avaliar e comparar a adoção de determinadas práticas tributárias que possivelmente influenciam a ETR das empresas no Brasil. As práticas tributárias previstas na legislação tributária brasileira, que foram possíveis de serem observadas nas demonstrações financeiras publicadas e que serviram como base para o estudo foram: i) Depreciação Acelerada; ii) Depreciação Acelerada Incentivada; iii) Juros Sobre o Capital Próprio; e iv); Incentivos Fiscais;

A partir de uma segregação por setor, nota-se o de energia elétrica como mais representativo dentre a amostra de empresas. As empresas de energia elétrica estão inseridas no setor de utilidade pública e consequentemente são empresas altamente reguladas. Isso pode justificar o fato de serem mais representativas em quantidade na carteira do ISE. Como para cada empresa classificada como certificada pelo ISE foi adotada uma empresa do mesmo setor para figurar o grupo de controle, consequentemente, tem-se o setor de energia elétrica mais representativo nos dois grupos analisados. 
Os resultados acerca da adoção de práticas tributárias (JSCP, DAI, e IF) permite concluir que para todos os anos em análise, de forma geral, tanto as empresas que são certificadas pelo ISE como as que não são certificadas, estão optando por alguma prática de maneira isolada ou conjunto de práticas tributárias combinadas.

Ao analisar a adoção de práticas tributárias pelas empresas certificadas e não certificadas separadamente, nota-se que o grupo de controle apresentou um menor número de empresas que escolheram alguma prática ou conjunto de práticas tributárias para todos os anos analisados. Ou seja, há uma maior opção por (uma ou mais) práticas tributárias no segmento de empresas que compõem o ISE. É possível sintetizar ainda que quanto à adoção de todas as práticas simultaneamente, tanto as empresas do ISE como as que não compõem o grupo, estão equivalentes.

Ao tomar como base os resultados obtidos de forma isolada, ou seja, individualizados para cada ano, é possível extrair uma conclusão considerando a hipótese levantada. Isto se dá pelo fato de se ter dados específicos para cada ano. Para os anos de 2010, 2011, 2012 e 2013 as ETRs das empresas socialmente responsáveis eram, de maneira geral, menores do que as que compõem o grupo de controle, o que permite concluir que as empresas socialmente responsáveis, denotadas pelo ISE, possuem uma maior tendência às práticas de elisão fiscal.

Por meio dos resultados de testes estatísticos apresentados não se pode afirmar com certeza que a adoção de alguma prática tributária por parte das empresas irá acarretar em uma ETR menor em relação às demais. É possível afirmar ainda que nem todas as práticas tributárias elencadas nesta pesquisa podem explicar a ETR, ou seja, estas não impactam positivamente ou negativamente a ETR.

Pelos resultados analisados tem-se que apenas a prática tributária denotada pela variável JSCP foi significativa à ETR. A expectativa foi corroborada considerando que esta variável foi significativa, bem como seu sentido foi inverso à ETR, permitindo concluir que o pagamento de juros sobre o capital próprio impacta as práticas de elisão fiscal corroborando com o que é apresentado em estudos anteriores (MALAQUIAS et al, 2007; CABELLO, 2012; POHLMANN; IUDÍCIBUS, 2006; CHAVES, 2010; SCHOENELL et al, 2013; NETO et. al. 2015; SANTOS, 2007).

Em relação ao teste da hipótese principal do estudo - há relação das empresas brasileiras que apresentam práticas socialmente responsáveis face à questão da elisão tributária- a hipótese foi corroborada à medida que a variável responsabilidade social (RS) foi significativa. 
Ao tomar como referência estudos anteriores (DICCICO, 2002; LANIS; RICHARDSON, 2011; LANIS; RICHARDSON, 2012; HOI et al, 2013; HUSEYNOV; KLAMM, 2012; TEIXEIRA; NOSSA, 2010; BASSEN; MEYER; SCHLANGE, 2006; ORLITZKY; BENJAMIN, 2001) a expectativa de que a variável RS fosse denotada por sinal diretamente proporcional à ETR não foi observada para a amostra desta pesquisa.

A análise descritiva pôde ser corroborada a partir do sinal inverso obtido para a variável RS em relação à ETR. É possível concluir que as empresas socialmente responsáveis, denotadas neste estudo pelo ISE, estão mais propensas às praticas de elisão fiscal quando comparadas às demais empresas não consideradas como socialmente responsável. Tal observação é sustentada ao verificar que as empresas certificadas estão adotando mais práticas tributárias quando comparadas às empresas do grupo de controle. Dentre as práticas temos o pagamento de Juros sob o capital próprio, adoção de depreciação acelerada e a opção por incentivos fiscais. Ao adotar as práticas tributárias elencadas neste estudo, as empresas reduzem o imposto e consequentemente tem-se um valor de ETR menor o que indica maior propensão à elisão fiscal.

Partindo da relevância desta questão, é essencial que a elisão fiscal faça parte da agenda de responsabilidade social corporativa adotada pelas empresas. O que nota-se por parte do Governo é o incentivo às práticas de elisão pelo fato de desenvolverem benefícios a fim de reduzir o pagamento de tributos por parte das empresas enquanto na realidade deveria exercer uma pressão sobre as empresas a fim de exigir maiores divulgações sobre estratégias na busca de se evitar as práticas de elisão fiscal.

Este estudo fornece uma visão voltada para a associação entre a responsabilidade social e elisão tributária e assim contribui a prolongar a literatura sobre o tema, principalmente no Brasil. As aplicações práticas do estudo permitem a análise, por parte das empresas e dos órgãos fiscalizadores, da adoção das práticas de elisão fiscal em empresas socialmente responsáveis. 


\section{REFERÊNCIAS}

AARBU, Karl Ove; MACKIE-MASON, Jeffrey K. Explaining underutilization of tax depreciation deductions: empirical evidence from Norway.International Tax and Public Finance, v. 10, n. 3, p. 229-257, 2003.

ABDELGHANY, K. E. Informational content of the cost of equity capital: empirical evidence. Managerial Auditing Journal,. 20, n. 9, p. 928-935, 2005.

ABRAHAM, M. O Planejamento Tributário e o Direito Privado. Ed. São Paulo: Quartier Latin, 2007.

ABRAHÃO, M. A. A elisão fiscal como ferramenta para o planejamento tributário. 2011.

ADAMS, Carol A. Internal organisational factors influencing corporate social and ethical reporting: Beyond current theorising. Accounting, Auditing \& Accountability Journal, v. 15, n. 2, p. 223-250, 2002.

ALMEIDA, F. C. R. Uma abordagem estruturada da renúncia de receita pública federal. Revista do Tribunal de Contas da União. Brasília, DF, v.31 n84, p. 19-62, abr/jun. 2000.

AVI-YONAH, R. S. Corporate social responsibility and strategic tax behavior. In: W. Scho"n (Ed.). Tax and Corporate Governance. Berlin: Springer, 2008. p. 183-198.

BASSEN, A.; MEYER, K.; SCHLANGE, J. The influence of corporate responsibility on the cost of capital. Available at SSRN 984406, 2006.

BEASLEY, Mark S. An empirical analysis of the relation between the board of director composition and financial statement fraud. Accounting Review, p. 443-465, 1996.

BELKAOUI, A. The Impact of the Disclosure of the Environmental Effects of Organizational Behavior on the Market. Financial Management, v. 5, n. 4 p. 26-31, 1976.

BM\&FBOVESPA. Índice de Sustentabilidade Empresarial (ISE). 2013. Disponível em: <

http://www.bmfbovespa.com.br/indices/ResumoIndice.aspx? Indice=ISE\&idioma=pt-br > Acesso em: 27 set. 2014.

BORGER, F. G. Responsabilidade social: efeitos da atuação social na dinâmica empresarial. Tese de Doutorado. Universidade de São Paulo. 2001

BRAGA, F. G. Elisão fiscal: a inconstitucionalidade da desconsideração de negócios jurídicos lícitos. Jus Navigandi, Teresina, ano 8, n. 359, jul. 2004. Disponível em: < http://jus2.uol.com.br/doutrina/texto.asp?id=5369 >. Acesso em: 20 jan. 2015.

BRASIL. Constituição (1988). Constituição da República Federativa do Brasil. Brasília, DF: Senado Federal, Editora, 1988. Disponível em: 
<https://www.planalto.gov.br/ccivil_03/constituicao/ConstituicaoCompilado.htm > Acesso em: 20 de fev. 2015.

Secretaria da Receita Federal. Depreciação acelerada incentivada para fins da legislação fiscal. 2010. Disponível em: <http://www.receita.fazenda.gov.br/pessoajuridica/dipj/2005/pergresp2005/pr379a380.h $\underline{\mathrm{tm}}>$. Acesso em: 21 jan. 2015.

Código Tributário Nacional. Lei 5.172, de 25 de outubro de 2010. Dispõe sobre o Sistema Tributário Nacional e institui normas gerais de direito tributário aplicáveis à União, Estados e Municípios. Disponível em: <http://www.planalto.gov.br/ccivil_03/leis/15172compilado.htm>. Acesso em: 21 jan. 2015.

. Conselho Federal De Contabilidade. Resolução CFC nº 986/03, de 21 de novembro de 2003. Aprova a NBC T 12- Da auditoria interna. Brasília: CFC, 2003. Disponível em:

<http://www.crc.org.br/legislacao/normas_tec/pdf/normas_tec_rescfc0986_2002.pdf > Acesso em: 30 jan. 2015.

BROWN, William O.; HELLAND, Eric; SMITH, Janet Kiholm. Corporate philanthropic practices. Journal of corporate finance, v. 12, n. 5, p. 855-877, 2006.

BURCH, E. E.; HENRY, W. R. Opportunity and incremental costs: attempt to define in systems terms: a comment. The Accounting Review, v. 49, n. 1, p. 119, 1974.

BURNS, E. M.; LERNER, R. E.; MEACHAM, S. História da Civilização Ocidental: do homem das cavernas às naves espaciais. Tradução de Donaldson M. Garshagen. 42. ed. São Paulo: Globo, 2003. v. 1.

CABELLO, O. G. Análise dos efeitos das práticas de tributação do lucro na effective tax rate (ETR) das companhias abertas brasileiras: uma abordagem da teoria das escolhas contábeis. São Paulo, 2012. Tese (Doutorado em Controladoria e Contabilidade) - Faculdade de Economia, Administração e Contabilidade, Universidade de São Paulo.

CAMARGO, R. Z. Responsabilidade social das empresas: formações discursivas em confronto. 2009. Tese (Doutorado) -Universidade de São Paulo, 2009.

CARROLL, Archie B. A three-dimensional concepttual model of corporate performance. Academy of Management Review,v. 4, p. 497-505, 1979.

The four faces of corporate citizenship. Business and society review, v. 100, n. 1, p. $1-7,1998$.

CARROLL, Archie B.; SHABANA, Kareem M. The business case for corporate social responsibility: a review of concepts, research and practice. International Journal of Management Reviews, v. 12, n. 1, p. 85-105, março. 2010.

CASTRO, Flávia de Almeida Viveiros de. Planejamento Tributário: A Lógica do Sistema e o Manicômio Jurídico Tributário. Ordem dos Advogados do Brasil / Seção 
Santa Catarina. No 106. Caderno de Temas Jurídico, p. 6/7. Florianópolis: Maio de 2002.

CHAVES, Francisco C. Planejamento tributário na prática: gestão tributária aplicada. Ed. São Paulo: Atlas, 2010.

CHEN, S.; CHEN, X.; CHENG, Q.; SHEYLIN, T. Are family firms more tax aggressive than non-family firms? Journal of Financial Economics, v. 95, n. 1, p. 4161, janeiro. 2010.

CLARKSON, Max E. A stakeholder framework for analyzing and evaluating corporate social performance. Academy of management review, v. 20, n. 1, p. 92-117, 1995.

COUTINHO, R. B. G.; MACEDO-SOARES; T. D. L. V. Gestão estratégica com responsabilidade social: arcabouço analítico para auxiliar sua implementação em empresas no Brasil. Revista de Administração Contemporânea, Curitiba, v. 6, n. 3, p. 75-96, sept./dec. 2002.

DEPOERS, Florence. A cost benefit study of voluntary disclosure: Some empirical evidence from French listed companies. European Accounting Review, v. 9, n. 2, p. 245-263, 2000.

DEEGAN, C. Introduction: The legitimitising effect of social environmental disclosures -a theoretical foundation. Accounting, Auditing and Accountability, v. 15, n. 3, p. 282-311, maio. 2002.

DE LA PEÑA, Isabel. Is tax the next big corporate social responsibility issue?

International Centre for Tax and Development, junho. 2014.

DENZIN, Norman K. Interpretive ethnography. Zeitschrift für

Erziehungswissenschaft, v. 3, n. 3, p. 401-409, 2000.

DESAI, M. A.; DHARMAPALA, D. CSR and taxation: the missing link. Leading Perspectives (Winter), v. 4, n. 5. 2006.

Corporate tax avoidance and high-powered incentives. Journal of Financial Economics, v. 79, n. 1, p. 145-179, janeiro. 2006.

DIAMOND, Douglas W. Optimal Release of Information By Firms. The Journal of Finance, v. 40, issue 4, p. 1071-1094, September, 1985. Acesso em: 20 Set. 2013.

DICICCO, Joel. The death of corporate tax. Journal of public budgeting, Accounting \& Financial Management, Boca Raton, v. 14, n. 3, p. 361-393, 2002.

DOUGHERTY, Christopher. Introduction to econometrics. Oxford University Press, 2007.

DYRENG, Scott D.; HANLON, Michelle; MAYDEW, Edward L. Long-run corporate tax avoidance. The Accounting Review, v. 83, n. 1, p. 61-82, 2008.

FABRETII, L. C. Contabilidade Tributária. 7. ed. São Paulo: Atlas, 2001. 
FAMA, E. F., \& JENSEN, M. C. Separation of ownership and control. Journal of Law and Economics, v. 26, p. 301-325, 1983.

FERREIRA, D. F. Estatística Multivariada (2nd ed.). Lavras: Editora UFLA. (2011)

FERNANDES, V. E. de A. Investimento na avaliação de empresas no Brasil: uma análise de aderência entre a teoria e a prática de mercado. 2011.

FIELDS, Thomas D. et al. Empirical Research on accounting choice. Journal of Accounting and Economics, Rochester, v. 31, n. x, p. 225-307. 2001.

FISHER, J. Fairer Shores: Tax Havens, Tax Avoidance and Corporate Social Responsibility. Boston University Law Review, v. 94, p. 337. 2014.

FORMIGONI, H. A influência dos incentivos fiscais sobre a estrutura de capital e a rentabilidade das companhias abertas brasileiras não financeiras. São Paulo, 2008. Tese (Doutorado em Controladoria e Contabilidade) - Programa de Pós Graduação em Ciências Contábeis, Departamento de Contabilidade e Atuária, Faculdade de Economia, Administração e Contabilidade da Universidade de São Paulo.

FRANK, M.; LYNCH, L.; REGO, S. Tax reporting aggressiveness and its relation to aggressive financial reporting. The Accounting Review, v. 84, n. 2, p. 467-496, março. 2009.

FREEDMAN, Judith. Tax and corporate responsibility. Tax Journal 695, v. 2, p. 1-4, junho. 2003.

FREEMAN, R. Edward; MCVEA, John. A stakeholder approach to strategic management. 2001.

FREISE, A.; LINK, S.; MAYER, S. Taxation and corporate governance - The state of the art. Springer-Verlag Berlin Heidelberg, 2008.

FREITAS, L. Carlos de; SILVA, Márcio Lopes da; MACHADO, Carlos Cardoso. Influência do cálculo de depreciação no imposto de renda e no fluxo de caixa de uma atividade de transporte florestal. Revista Árvore, v. 31, n. 2, p. 257-264, 2007.

FRIEDMAN, M. The Social Responsibility of Business is to Increase its Profits. The New York Times Magazineset. 1970.

GALLO, Mauro Fernando. Uma contribuição ao estudo do planejamento tributário nos processos de fusão, cisão e incorporação. 2002. Dissertação (Mestrado em Controladoria e Contabilidade Estratégica) Faculdade de Ciências Econômicas de São Paulo-, Centro Universitário Alves Penteado, São Paulo, 2002.

GIRÃO, Luiz Felipe de Araújo Pontes. Assimetria informacional, insider trading e avaliação de empresas: evidências no mercado de capitais brasileiro. 2013.

GODFREY, P. C. The relationship between corporate philanthropy and shareholder wealth: a risk management perspective. Academy of Management Review, v. 30, n. 4, p. 777-798, 2004. 
GOMES, Adriano; MORETTI, Sérgio. A responsabilidade e o social: uma discussão sobre o papel das empresas. Ed. Editora Saraiva, 2007.

GONÇALVES, Rodrigo de Souza. Evidenciação de projetos sociais por empresas de capital aberto. 2006. Dissertação (Mestrado em Controladoria e Contabilidade Estratégica), Centro Universitário Alves Penteado, São Paulo, 2006.

GRAY, R.; KOUHY, R.; LAVERS, S. Corporate social and environmental reporting: A review of the literature and a longitudinal study of disclosure. Accounting, Auditing and Accountability Journal,v. 8, n. 2, p. 47-77. 1995.

GUBERT, P. A. P. Planejamento tributário: análise jurídica e ética. 2. ed. Curitiba: Jurua, 2003.

GUJARATI N. Damodar (2003). Basic Econometrics, $4^{\text {th }}$ Edition, McGraw-Hill, Chapter 16.

GUPTA, Sanjay; NEWBERRY, Kaye. Determinants of the variability in corporate effective tax rates: Evidence from longitudinal data. Journal of Accounting and Public Policy, v. 16, n. 1, p. 1-34, 1997.

GUTIERREZ, M. D. Planejamento tributário: elisão e evasão fiscal. Ed. São Paulo: Quartier Latin, 2006.

HANLON, M.; HEITZMAN, S. Shane. A review of tax research. Journal of Accounting and Economics, Rochester, v. 50, p. 127-178, 2010.

HAIR, J. F., Black, W. C., Babin, B. J., Anderson, R. E., \& Tatham, R. L. (2009). Análise Multivariada de Dados (6th ed.). Porto Alegre: Bookman.

HEAL, Geoffrey. Corporate Social Responsibility: an Economic and Financial Framework. The Geneva Papers, n. 30, p. 387-409, janeiro. 2005. Disponível em: < www.palgrave-journals.com/gpp >. Acesso em: 20 jan. 2015.

HUSEYNOV, F.; KLAMM, B. K. Tax avoidance, tax management and corporate social responsibility. Ed. Dakota: Editora, 2012.

ICHIHARA, Yoshiaki. Direito Tributário, São Paulo: Atlas, 2006

JANSSEN, Boudewijn. Effective tax rate (ETR) measures: alternatives and their validity. MARC and Department of Accounting and Auditing, Faculty of Economics and Business Administration, 2000.

JENKINS, R.; NEWELL, P. CSR, Tax and Development. Third World Quarterly, v. 34, n. 3, p.378-396, maio. 2013.

KARKOTLI, Gilson; ARAGÃO, Sueli Duarte. Responsabilidade social: uma contribuição à gestão transformadora das organizações. 1. ed. Petrópolis: Vozes, 2004.

KNUUTINEN, Reijo. Corporate Social Responsibility, Taxation and Aggressive Tax Planning. Nordic Tax Journal, v. 2014, n. 1, p. 36-75, 2014. 
KURUCZ, E.; COLBERT, B.; WHEELER, D. The business case for corporate social responsibility. The Oxford Handbook of Corporate Social Responsibility, Oxford, p. 83-112. 2008

LAKATOS, Eva Maria; DE ANDRADE MARCONI, Marina. Metodologia do trabalho científico: procedimentos básicos, pesquisa bibliográfica, projeto e relatório, publicações e trabalhos científicos. 2001.

LANDOLF, U. Tax and corporate responsibility. International. Tax Review, v. 29, p. 69, 2006.

LANIS, Roman; RICHARDSON, Grant. The effect of board of director composition on corporate tax aggressiveness. Journal of Accounting and Public Policy, v. 30, n. 1, p. 50-70, janeiro. 2011.

Corporate social responsibility and tax aggressiveness: aan empirical analysis.

Journal of Accounting and Public Policy, v. 31, n. 1, p. 86-108,2012.

Is Corporate Social Responsibility performance Associated with Tax Avoidance? Springer Science Business Media Dordrecht, p. 1-19, janeiro. 2014.

LANG, Mark; LUNDHOLM, Russell. Cross-sectional determinants of analyst ratings of corporate disclosures. Journal of accounting research, p. 246-271, 1993.

LEUZ, Christian; WYSOCKI, Peter D. Economic consequences of financial reporting and disclosure regulation: A review and suggestions for future research. Available at SSRN 1105398, 2008.

LOEBBECKE, James K.; EINING, Martha M.; WILLINGHAM, John J. Auditors experience with material irregularities-frequency, nature, and detectability. Auditing-a journal of practice \& theory, v. 9, n. 1, p. 1-28, 1989.

MARCONDES, A. W.; BACARJI, C. D. ISE: sustentabilidade no mercado de Capitais. 1. ed. São Paulo: Record Editora, 2010.

MARINS, James. Elisão tributária e sua regulação. São Paulo: Dialética, 2002.

MATSUMURA, Ella Mae; TUCKER, Robert R. Fraud detection: A theoretical foundation. Accounting Review, p. 753-782, 1992.

MILANI FILHO, Marco Antonio Figueiredo. Responsabilidade social e investimento social privado: entre o discurso e a evidenciação. Revista Contabilidade \& Finanças, v. 19, n. 47, p. 89-101, 2008.

MURCIA, Fernando Dal-Ri; DOS SANTOS, Ariovaldo. Fatores determinantes do nível de disclosure voluntário das companhias abertas no Brasil. Revista de Educação e Pesquisa em Contabilidade (REPeC), v. 3, n. 2, p. 72-95, 2009.

MUSSA, Adriano; ROGERS, Pablo; SECURATO, José Roberto. Modelos de retornos esperados no mercado brasileiro: testes empíricos utilizando metodologia preditiva. Revista de Ciências da Administração, v. 11, n. 23, p. 192-216, 2009. 
DE SOUSA NETO, Jose Antonio et al. JUROS SOBRE CAPITAL PRÓPRIO COMO FORMA DE REMUNERAÇÃO DE ACIONISTAS: um estudo sobre o conflito de agência e as práticas de planejamento tributário. Revista de Administração FACES Journal, v. 13, n. 4, 2015.

ORLITZKY, Marc; BENJAMIN, John D. Corporate social performance and firm risk: A meta-analytic review. Business \& Society, v. 40, n. 4, p. 369-396, 2001.

PAULSEN, Leandro. Direito tributário - constituição e código tributário à luz da doutrina e jurisprudência. 7. ed. Porto Alegre: Livraria do Advogado, 2005.

PARANAIBA, Adriano; MARQUES, Ieso Costa. POLÍTICAS DE INCENTIVOS FISCAIS E A DISPUTA PELO DESENVOLVIMENTO REGIONAL INDUSTRIAL. Administra-Ação, n. 8, p. 19-25, 2013.

PENA, Joana Filipa Rodrigues Carvalho. Estudo da Relação entre a

Responsabilidade Social e o Desempenho Empresarial. 2011.- Escola de Economia e Gestão, Universidade do Minho, 2011.

PIQUERAS, Tatiana M. A relação das diferenças entre o lucro contábil e o lucro tributável (book-tax differences) e gerenciamento de resultados no Brasil. 2010. 66 p. Dissertação (Mestrado em Controladoria e Contabilidade) - Faculdade de Economia, Administração e Contabilidade, Universidade de São Paulo, Ribeirão Preto, 2010.

POHLMANN, Marcelo C.; IUDÍCIBUS, Sérgio de. Tributação e política tributária. Ed. São Paulo: Atlas, 2006.

POHLMANN, M. C. Análise de Conglomerados. In L. J. Corrar, E. Paulo, \& J. M. D. Filho (Eds.), Análise multivariada: para cursos de administração, ciências contábeis e economia. São Paulo: Atlas, 2007.

PORTER, M. E.; KRAMER, M. R. Strategy and society: The link between competitive advantage and corporate social responsibility. Harvard Business Review, v. 84, n. 12, p. $78-92$, . dezembro. 2006.

REGO, S. Tax Avoidance Activities of U.S. Multinational Corporations. Contemporary Accounting Research, Iowa City, v. 20, p. 805-833, 2003.

REIS, E. (2001a). Estatística Multivariada Aplicada (2nd ed.). Lisboa: Edições Sílabo Lda.

REIS, E. (2001b). Estatística Multivariada Aplicada (2nd ed.). Lisboa: Edições Sílabo Lda.

REZAEE, Zabihollah. Causes, consequences, and deterence of financial statement fraud. Critical Perspectives on Accounting, v. 16, n. 3, p. 277-298, 2005.

RIAHI-BELKAOUI, Ahmed; KARPIK, P. G. Determinants of the Corporate Decision to Disclosure Social Information. Accounting, Auditing and Accountability Journal, Vol. 1 No. (1), pp. 36-51, Dec, 1988. Acesso em: 12 Jan. 2015. 
RICHARDSON, Roberto Jarry et al. Pesquisa Social: métodos e técnicas. 3. ed. São Paulo: Atlas, 1999.

ROBERTS, R. W. Determinants of corporate social responsibility disclosure: An application of stakeholder theory. Accounting, Organizations and Society, EUA, v. 17, p. 595-612, agosto.1992.

ROBINSON, J. R.; KISES, S. A.; WEAVER, C. D. Performance measurement of corporate tax departments. Account. Rev, . 85, p. 1035-1064, 2010.

ROBBINS, S.; COULTER, M. Administración. 5a. ed. Rio de Janeiro: Prentice Hall do Brasil, 1998.

SANCOVSCHI, M.; SILVA, A. H. C. Evidenciação social corporativa: estudo de caso da empresa Petróleo Brasileiro SA. Sociedade, Contabilidade e Gestão, v. 1, n. 1, 2010.

SANTIAGO, Marlene Ferreira. O efeito da tributação no planejamento financeiro das empresas prestadoras de serviços: um estudo de caso de desenvolvimento regional. 2006. 139 f. Dissertação (Mestrado em Gestão e Desenvolvimento Regional do Departamento de Economia, Contabilidade e Administração da Universidade de Taubaté em 2006) - Universidade de Taubaté, SP, 2006.

SANTOS, Ariovaldo dos. Quem está pagando juros sobre capital próprio no Brasil? Revista de Contabilidade e Finanças, São Paulo, , p. 33-44, jun. 2007. Edição 30 Anos de Doutorado

SCHOLES MYRON, S.; WOLFSON MARK, A. Taxes and Business Strategy. Ed. Prentice Hall, New Jersey, 1992.

SCHOENELL, Camila et al. Juros Sobre Capital Próprio: Um Estudo da Economia Tributária nas Empresas Gol e Tam. In: Conferência Interamericana de Contabilidade, 30., 2013, Uruguai. Anais... Uruguai, 2013.

SHACKELFORD, D. A.; SHEVLIN, T. Empirical tax research in accounting. Seattle, 2001.

SILVA, Andréa de Oliveira; GONÇALVES, Rodrigo de Souza. Abaixo da linha do Equador não existe pecado: uma reflexão crítica sobre a aplicação dos conceitos de marketing social no país dos tupiniquins. In: Simpósio Nacional de Gestão de Competências Organizacionais - SINCOMP, 4., 2004, São Paulo. São Paulo: UniFecap, 2004.

SIKKA, Prem; WILLMOTT, Hugh. The dark side of transfer pricing: Its role in tax avoidance and wealth retentiveness. Critical Perspectives on Accounting, v. 21, n. 4, p. 342-356, 2010.

SIKKA, Prem. Smoke and mirrors: corporate social responsibility and tax avoidance A reply to Hasseldine and Morris. Accounting Forum, Elsevier, p. 15-28, 2013. 
SILVEIRA, Alexandre di Miceli da. et al. Estrutura de governança e valor das Companhias Abertas Brasileiras. Revista de Administração de Empresas, São Paulo, v. 43, n. 3, 2003.

SMITH, T. Institutional and social investors find common ground. Journal of Investing, , v. 14, n. 3, p. 57-65, 2005.

SOUZA, Júlia; COSTA, Thiago de Melo Teixeira da. Responsabilidade Social Empresarial e Desenvolvimento Sustentável: Conceitos, Práticas e Desafios para a Contabilidade-DOI: http://dx. doi. org/10.15603/1982-8756/roc. v8n15p213238. Revista Organizações em Contexto-online, v. 8, n. 15, p. 213-238, 2012.

SOUSA FILHO, R. C. et al. Análise dos efeitos contábeis e tributários da extinção do reconhecimento contábil da inflação no Brasil no período 19962000 ( $1^{\text {a }}$ parte). Informações Objetivas. IOB, Caderno de Temática Contábil e Balanços. São Paulo, ano 35, v. 12, mar. 2001.

SPICER, B. Investors corporate social performance and information disclosure: an empirical study. The Accounting Review, v. 53, p. 94-111, 1978.

STOCK J. and WATSON M. (2007). Introduction to Econometrics, $2^{\text {nd }}$ Edition, Pearson, Chapter 10.

SUNDARAM, Anant K.; INKPEN, Andrew C. The corporate objective revisited. Organization science, v. 15, n. 3, p. 350-363, 2004.

TANG, T. Book-tax differences: a function of accounting-tax misalignment, earnings management and tax management (empirical evidence from china). Ed. Washington: 2006.

TEIXEIRA, Evimael Alves; NOSSA, Valcemiro. Sinalizando responsabilidade social: relação entre o índice de sustentabilidade empresarial e a estrutura de capital das empresas. In: CONGRESSO ASSOCIAÇÃO NACIONAL DOS PROGRAMAS DE PÓS-GRADUAÇÃO EM CIÊNCIAS CONTÁBEIS. 2010.

TINOCO, João Eduardo Prudêncio. Balanço Social: uma abordagem da transparência e da Responsabilidade Pública das Organizações. 1. Ed. São Paulo: Atlas, 2001.

TROTMAN, Ken T.; BRADLEY, Graham W. Associations between social responsibility disclosure and characteristics of companies. Accounting, organizations and society, v. 6, n. 4, p. 355-362, 1981.

TUCKMAN, Bruce W. RELATIONS OF ACADEMIC PROCRASTINATION, RATIONALIZATIONS, AND PERFORMANCE IN A WEB COURSE WITH DEADLINES 1. Psychological Reports, v. 96, n. 3c, p. 1015-1021, 2005.

WADDOCK, S. A.; GRAVES, S. B. The corporate social performance - financial performance link. Strategic Management Journal, v. 18, n. 4, p. 303-319, 1997.

WALLACE, RS Olusegun; NASER, Kamal. Firm-specific determinants of the comprehensiveness of mandatory disclosure in the corporate annual reports of firms 
listed on the stock exchange of Hong Kong. Journal of Accounting and Public policy, v. 14, n. 4, p. 311-368, 1996.

WATTS, Ross L. Accounting choice theory and market-based research in accounting. British Accounting Review. Rochester, v. 24, p. 235-267, 1992.

WATTS, Ross L.; ZIMMERMAN, J. L. Positive accounting theory. NJ: Prentice-Hall, Englewood Cliffs, 1986.

Positive accounting theory: a ten year perspective. The

Accounting Review. [S.1.], v. 65, n.1, p. 131-156, Jan. 1990.

WEISBACH, D. A. Ten Truths about Tax Shelters. Ed. Chicago: Editora, 2001.

WOOLDRIDGE J.M. (2003). Introductory Econometrics, $2^{\text {nd }}$ Edition, Thomson, Chapters 13 and 14.

YLÖNEN, Matti; LAINE, Matias. For logistical reasons only? A case study of tax planning and corporate social responsibility reporting. Critical Perspectives on Accounting, 2014. 
ANEXO A - Mensurações da elisão fiscal

\begin{tabular}{|c|c|c|c|c|c|c|c|}
\hline $\begin{array}{l}\text { sures of tax avoldance. } \\
\text { Measure }\end{array}$ & Computation & Description & $\begin{array}{c}\text { Impact } \\
\text { accounting } \\
\text { earnings? }\end{array}$ & $\begin{array}{l}\text { Reflect deferral } \\
\text { strategies? }\end{array}$ & $\begin{array}{l}\text { Reflect non- } \\
\text { conforming } \\
\text { avoidance? }\end{array}$ & $\begin{array}{c}\text { Reflect } \\
\text { conforming } \\
\text { avoidance? }\end{array}$ & $\begin{array}{l}\text { Computable } \\
\text { by } \\
\text { jurisdiction? }\end{array}$ \\
\hline GAAP ETR & $\begin{array}{c}\text { Worldwide total income tax expense } \\
\text { Worldwide total pre- tax accounting income }\end{array}$ & $\begin{array}{l}\text { Total tax expense per dollar of pre-tax } \\
\text { book income }\end{array}$ & Yes & No & Yes & No & Yes \\
\hline Current ETRa & $\frac{\text { Worldwide current income tax expense }}{\text { Worldwide total pre-tax accounting income }}$ & $\begin{array}{l}\text { Current tax expense per dollar of pre-tax } \\
\text { book income }\end{array}$ & Maybe & Yes & Yes & No & Yes \\
\hline Cash ETRb & $\frac{\text { Worldwide cash taxes paid }}{\text { Worldwide total pre-tax accounting income }}$ & $\begin{array}{l}\text { Cash taxes paid per dollar of pre-tax book } \\
\text { income }\end{array}$ & No & Yes & Yes & No & No \\
\hline Long-run cash ETR & PðWorldwide total pre—-tax accounting incomeP & by the sum of pre-tax earnings over $n$ years & No & Yes & Yes & No & No \\
\hline ETR Differential & Statutory ETR - GAAP ETR & $\begin{array}{l}\text { The difference of between the statutory ETR } \\
\text { and the firm's GAAP ETR }\end{array}$ & Yes & No & Yes & No & No \\
\hline DTAX & $\begin{array}{c}\text { Error term from the following regression: } \\
\text { ETR differential } x \text { Pre-tax book }\end{array}$ & $\begin{array}{l}\text { The unexplained portion of the ETR } \\
\text { differential }\end{array}$ & Yes & No & Yes & No & No \\
\hline Total BTD ${ }^{\mathrm{f}}$ & $\begin{array}{l}\text { income }=\mathrm{a}+\mathrm{b} \times \text { Controls+e } \\
\text { Pre-tax book income-((U.S. CTE }+ \text { Fgn CTE)/ } \\
\text { U.S. STR)-(NOLt-NOLt-1)) }\end{array}$ & $\begin{array}{l}\text { The total differences between book and } \\
\text { taxable incomes }\end{array}$ & $\begin{array}{l}\text { Yes for a portion, } \\
\text { no for a portion }\end{array}$ & Yes & Yes & No & Yes (U.S.) \\
\hline $\begin{array}{l}\text { Temporary BTD } \\
\text { Abnormal total BTD }\end{array}$ & $\begin{array}{c}\text { Deferred tax expense/U.S. STR } \\
\text { Residual from BTD/TAit=bTAit+bmi+eit }\end{array}$ & $\begin{array}{l}\text { A measure of unexplained total book-tax } \\
\text { differences }\end{array}$ & $\begin{array}{l}\text { No } \\
\text { Yes for a portion, } \\
\text { no for a portion }\end{array}$ & $\begin{array}{l}\text { Yes } \\
\text { Yes }\end{array}$ & $\begin{array}{l}\text { Yes } \\
\text { Yes }\end{array}$ & $\begin{array}{l}\text { No } \\
\text { No }\end{array}$ & $\begin{array}{l}\text { Yes (U.S.) } \\
\quad \text { No }\end{array}$ \\
\hline $\begin{array}{l}\text { Unrecognized tax } \\
\text { benefits }\end{array}$ & Disclosed amount post-FIN48 & $\begin{array}{l}\text { Tax liability accrued for taxes not yet } \\
\text { paid on uncertain positions }\end{array}$ & Yes & If uncertain & Yes, some & Yes, some & No \\
\hline Tax shelter activity $\quad \mathrm{I}$ & $\begin{array}{l}\text { Indicator variable for firms accused of } \\
\text { engaging in a tax shelter }\end{array}$ & $\begin{array}{l}\text { Firms identified via firm disclosures, } \\
\text { the press, or IRS confidential data }\end{array}$ & $\begin{array}{l}\text { Depends on the } \\
\text { type of shelter }\end{array}$ & $\begin{array}{c}\text { Shelter may be a } \\
\text { deferral strategy; } \\
\text { but not an } \\
\text { overall measure }\end{array}$ & $\begin{array}{l}\text { Not overall- } \\
\text { measure is } \\
\text { transaction } \\
\text { based }\end{array}$ & $\begin{array}{c}\text { Not overall- } \\
\text { measure is } \\
\text { transaction } \\
\text { based }\end{array}$ & Unlikely \\
\hline Marginal tax rate j & Simulated marginal tax rate & $\begin{array}{l}\text { Present value of taxes on an additional } \\
\text { dollar of income }\end{array}$ & No & Yes & Yes & Yes & $\begin{array}{l}\text { Not with } \\
\text { existing data }\end{array}$ \\
\hline
\end{tabular}

a May impact accounting earnings if the item that changes the Current ETR is not a temporary difference.

bA more direct measure of taxes actually paid but numerator and denominator may be unaligned. The measure is more volatile year-to-year than the two measures above. Can also deflate by pre-taxincome adjusted for special items.

cSee Dyreng et al. (2008). Measured generally over 3-10 years. Longer may be better but fewer available firms. Eliminates some of the volatility in Cash ETR. Can also deflate by pretax income adjusted for special items.

d If using the same U.S. statutory tax rate for all firms, comparing GAAP ETRs yields similar inferences.

e The terms on the right-hand side can vary depending on the research question. Model is only as good as the variables included as determinants. What variables to include depends on how one interprets the actions of the manager with regard to that construct-action taken to reduce taxes or the reduction of tax is a byproduct.

fGrossing up current tax expense by the statutory tax rate to estimate taxable income is subject to well-known measurement error (Hanlon, 2003). Subtracting the change in the NOL is intended to capture changes in taxable income that are not captured by the current tax expense because the firm is a tax-loss firm and current tax expense is thus reported as zero (or a negative if they have NOL carrybacks). Researcher should conduct sensitivity tests for the cases where measurement error is likely the highest as in Hanlon et al. (2005).

gSee Desai and Dharmapala (2006). A variety of other right-hand side variables could be included depending on what the research question calls for in terms of "controls."TA (Total Accruals) intended to control for earnings management.

h The measure is a financial accounting accrual subject to the conservative or "aggressive"nature of the firm for financial accounting purposes.

iThe measure will not include firms that are not caught nor will it include firms that can otherwise avoid tax successfully and do not engage in shelters.

jSee Shevlin (1990), Graham, (1996a, b), Blouin et al. (2010), Graham and Kim (2009). This measure is not really a measure of avoidance but may provide information when comparing firms with varying importance for financial accounting earnings (e.g., private companies versus public companies). 140

M. Hanlon, S. Heitzman / journal of Accounting and Economics 50 (2010) 127-178

Fonte: (HANLON, HEITZMAN, 2010, p. 140). 
ANEXO B - EMPRESAS CERTIFICADAS PELO ISE

Empresas certificadas pelo ISE - 2009 a 2013

\begin{tabular}{|c|c|c|c|c|}
\hline 2009 & 2010 & 2011 & 2012 & 2013 \\
\hline AES Tietê & AES Tietê & AES Tietê & AES Tietê & AES Tietê \\
\hline Braskem & Braskem & Braskem & Braskem & Braskem \\
\hline BRF Foods & BRF Foods & BRF Foods & BRF Foods & BRF Foods \\
\hline Cemig & Cemig & Cemig & $\mathrm{CCR}$ & CCR \\
\hline Cesp & Cesp & Cesp & Cemig & Cemig \\
\hline Coelce & Coelce & Coelce & Cesp & Cesp \\
\hline Copel & Copasa & Copasa & Coelce & Coelce \\
\hline CPFL Energia & Copel & Copel & Copasa & Copasa \\
\hline Dasa & CPFL Energia & CPFL Energia & Copel & Copel \\
\hline Duratex & Duratex & Duratex & CPFL Energia & CPFL Energia \\
\hline Eletrobras & Eletrobras & Ecorodovias & Duratex & Duratex \\
\hline Eletropaulo & Eletropaulo & Eletrobras & Ecorodovias & Ecorodovias \\
\hline Embraer & Embraer & Eletropaulo & Eletrobras & Eletrobras \\
\hline Energias BR & Energias BR & Embraer & Eletropaulo & Eletropaulo \\
\hline Even & Even & Energias BR & Energias BR & Embraer \\
\hline Fibria & Fibria & Even & Even & Energias BR \\
\hline Gerdau & Gerdau & Fibria & Fibria & Even \\
\hline Gerdau Met & Gerdau Met & Gerdau & Gerdau & Fibria \\
\hline Inds Romi & Inds Romi & Gerdau Met & Gerdau Met & Fleury \\
\hline Light S/A & Light S/A & Light S/A & Light S/A & Gerdau \\
\hline Natura & Natura & Natura & Natura & Gerdau Met \\
\hline Sabesp & Sabesp & Sabesp & Sabesp & Klabin \\
\hline Suzano Papel & Suzano Papel & Suzano Papel & Suzano Papel & Light S/A \\
\hline Tim Part S/A & Tim Part S/A & Tim Part S/A & Telefonica & Natura \\
\hline Tractebel & Tractebel & Tractebel & Tim Part S/A & OI \\
\hline \multirow[t]{7}{*}{ Usiminas } & Ultrapar & Ultrapar & Tractebel & Sabesp \\
\hline & Vale & Vale & Ultrapar & Suzano Papel \\
\hline & & & Vale & Telefonica \\
\hline & & & WEG & Tim Part S/A \\
\hline & & & & Tractebel \\
\hline & & & & Vale \\
\hline & & & & WEG \\
\hline
\end{tabular}




\section{ANEXO C — EMPRESAS NÃO CERTIFICADAS PELO ISE}

Empresas não certificadas pelo ISE - 2009 a 2013

\begin{tabular}{|c|c|c|c|c|}
\hline 2009 & 2010 & 2011 & 2012 & 2013 \\
\hline Alupar & Alupar & Alupar & Alupar & Alupar \\
\hline Ceee-Gt & Bradespar & Bradespar & Arteris & Arteris \\
\hline Celesc & Casan & Casan & Bradespar & Casan \\
\hline Celul Irani & Ceee-Gt & Ceee-Gt & Casan & Ceee-Gt \\
\hline Cemar & Celesc & Celesc & Ceee-Gt & Celesc \\
\hline Cosern & Celul Irani & Celul Irani & Celesc & Celul Irani \\
\hline Emae & Cemar & Cemar & Celul Irani & Cemar \\
\hline Embratel & Cosern & Cosern & Cemar & Cosern \\
\hline Eneva & Emae & Emae & Cosern & Emae \\
\hline Equatorial & Embratel & Embratel & Emae & Embratel \\
\hline Eucatex & Eneva & Eneva & Embratel & Eneva \\
\hline Ferbasa & Equatorial & Equatorial & Eneva & Equatorial \\
\hline Hypermarcas & Eucatex & Eucatex & Equatorial & Eucatex \\
\hline Inepar & Ferbasa & Ferbasa & Eucatex & Ferbasa \\
\hline Iochp-Maxion & Hypermarcas & Hypermarcas & Ferbasa & Hypermarcas \\
\hline JBS & Inepar & Iochp-Maxion & Hypermarcas & Iochp-Maxion \\
\hline Neoenergia & Iochp-Maxion & JBS & JBS & JBS \\
\hline Panatlantica & JBS & MMX Miner & La Fonte Tel & La Fonte Tel \\
\hline Sanepar & MMX Miner & Neoenergia & Lupatech & Lupatech \\
\hline Sid Nacional & Neoenergia & Panatlantica & MMX Miner & Melhor SP \\
\hline Suzano & Panatlantica & Sanepar & Neoenergia & MMX Miner \\
\hline Taesa & Sanepar & Suzano & Panatlantica & Neoenergia \\
\hline Tecnisa & Suzano & Taesa & Sanepar & Panatlantica \\
\hline Tempo & Taesa & Tecnisa & Suzano & Qualicorp \\
\hline Tran Paulist & Tecnisa & Tran Paulist & Taesa & Sanepar \\
\hline \multirow[t]{7}{*}{ Unipar } & Tran Paulist & Triunfo & Tecnisa & Suzano \\
\hline & Unipar & Unipar & Tran Paulist & Taesa \\
\hline & & & Triunfo & Tecnisa \\
\hline & & & Unipar & Telebras \\
\hline & & & & Tran Paulist \\
\hline & & & & Triunfo \\
\hline & & & & Unipar \\
\hline
\end{tabular}

